Portland State University

PDXScholar

\title{
An Ornithological Investigation of the Relationships Among Species Assemblages in Diverse Landscapes in Portland, Oregon
}

Trevor Attenberg

Portland State University

Follow this and additional works at: https://pdxscholar.library.pdx.edu/mem_gradprojects

Part of the Environmental Indicators and Impact Assessment Commons, and the Environmental Monitoring Commons Let us know how access to this document benefits you.

\section{Recommended Citation}

Attenberg, Trevor, "An Ornithological Investigation of the Relationships Among Species Assemblages in Diverse Landscapes in Portland, Oregon" (2015). Master of Environmental Management Project Reports. 46.

https://pdxscholar.library.pdx.edu/mem_gradprojects/46

https://doi.org/10.15760/mem.44

This Project is brought to you for free and open access. It has been accepted for inclusion in Master of Environmental Management Project Reports by an authorized administrator of PDXScholar. Please contact us if we can make this document more accessible: pdxscholar@pdx.edu. 


\title{
An Ornithological Investigation of the Relationships Among Species Assemblages in Diverse Landscapes in Portland, Oregon
}

By Trevor Attenberg

\begin{abstract}
This study involves geographic variables of the urban landscape and how they affect bird species assemblage. I utilized bird point count data from observation sites in the Portland, OR metropolitan region provided by Portland Environmental Services. Species data and its relationship with environmental variables were evaluated using Bray-Curtis Dissimilarity measurements together with Non-metric Multidimensional scaling (NMDS) to provide a clear image of the spatial relationships between sites. Land classification, water and canopy in $500 \mathrm{~m}$ buffers were quantified in order to describe important geographic variability among collection areas of bird data. Patterns indicating spatial trends in the urban landscape emerged. Three groups of sites (Wetland, Built, and Forest) representing a tiered breakdown were formed to further inspect these trends and their effect on bird species communities. The breakdown trend extended from low-lying, heavily industrialized areas with extensive wetland or former wetland, to upland with less wetlands, some forest, and moderate-intensity suburban development at middle elevations, to heavily forested regions well upland in the large well-drained parklands and outer suburban terrain of the city. Bird species assemblages un-clustered across these trends suggest important landscapes for bird diversity throughout the city terrain, as well as interesting species associations. Unanticipated species finds, shifts in species diversity and indicator values among the clusters informs managers interested in maintenance and restoration of urban habitat in Portland.
\end{abstract}

\section{Introduction}

Urban ecology addresses and focuses on concerns of the impact of human population growth, and the spread of human footprints as manifested by chemical, air and water pollution; clearing and paving of once productive landscapes; runoff from impervious and barren surfaces; alteration and diversion of stream flow regimes; light and noise pollution; and subsequent changes to native species communities (Schueler, 1994; Finkenbine et al., 2000; FernandezJuricic and Jokimaki, 2001; Faulkner, 2004; Francis et al., 2009; Alberts et al., 2013; Adler and Tanner, 2013) especially on animal diversity. While urbanization may have a homogenizing effect on regional diversity, many urban and suburban aspects may benefit birds and their diversity (Blair, 1996; Ryder et al, 2010; Adler and Tanner, 2013). For example, the urban heat island effect, and supplemental feeding often allows birds to breed over larger portions of the year than in the wild (Adler and Tanner, 2013). On the other hand, urban heat and water bodies may combine to provide optimal conditions for vectors of diseases like the bird-killing WestNile Virus amidst concentrated bird populations-which is also a potentially deadly risk to humans (Reisen et al., 2008; Adler and Tanner, 2013); though birds may build immunity under such high exposure (Bradley et al., 2008).

Birds are an important aspect of urban ecology and landscape ecology (Nassauer, 1995). They are charismatic species, easily seen, and nearly universally known, if not understood by 
people in their wild or un-domesticated condition although some scientists opine birds are thus overrepresented in urban ecological literature (Gaston, 2010). Birds are usually the most commonly experienced of wildlife, with sounds and songs that can be heard, even in some of the most polluted and densely populated of cities, and with conspicuous behavior and often striking plumage. All this has made them popular among hobbyists, scientists, educators, artists, and casual observers alike (Luck and Smallbone, 2010). Thus, they are an important ecosystem service as far as the valuing of the environment is concerned. Birds can also be a limiting factor on insect pests in cities, while transporting useful and troublesome plants (Shochat et al., 2006, Knap et al., 2008). The diversity and ease of research of birds allows scientists to readily begin to understand ecosystem complexity and health, with species indicators of diverse behavioral niches and habitat types.

There has thus been considerable research on the effects of urban development on bird communities across different climatic zones and regions, including areas of the Pacific Northwest. Most literature on the matter suggests that native birds associate with native plants and plant communities, whereas non-native birds best associate with exotic plants and simplified plant community structures encouraged by paving and diminishment of wild landscapes (Mills et al., 1991; Case, 1996; Pavlik and Pavlik, 2000; Hennings and Edge, 2002). Native plants in some studies have proven to support a greater variety of lepidopterans and other insects, and by extension birds (Tallamy, 2007; Burghardt et al., 2009). Overall richness thus tends to decline with the simplification brought about by urbanization (Marzluff et al., 1998) although even these heavily built landscapes have complexities, with synanthropic and non-native species filling different habitat niches (Pickett et al., 2012). In addition to these studies, information can be extrapolated from research foci such as habitat fragmentation, loss, and contamination; spread of invasive species; and the behavior of predators. For example, an estimated 84 million house cats in the U.S. each kill 4-18 birds annually (500 million in total). The total annual bird-kill for all U.S. cats is about 3.7 billion (Gates, 2013). However, there is evidence that nest-predators in urban areas often focus more on human derived food than wild prey (Rodewald et al., 2010). Other urban nest predator populations may be controlled or displaced by larger predators as coyotes (Rodewald et al., 2010).

Evidence of the effects of urban conditions is thus mixed and somewhat nebulous. Effects of habitat loss are a bit more straight-forward. Prior to Euro-American settlement of the Willamette valley, an extensive lowland forest of diverse riparian deciduous trees, including alder, Oregon ash, and black cottonwood among other woody species thrived (Schumaker et al., 2003). This forest had formed a zone ranging from 2 to 10 miles wide along the river. Only about $20 \%$ of this forest exists today (Schumaker et al., 2003). Additionally, the valley supported oak savannah and grasslands maintained by burnings ignited intentionally by the Native Americans (Boyd, 1986; Schumaker et al., 2004). Little if any true examples of such fire dependent habitat exists today. An estimated $99 \%$ of lowland wet prairie and $58 \%$ of emergent wetlands has been converted for agriculture and urban development as of the late $20^{\text {th }}$ century assessments (Titus et al., 1996; Schumaker et al., 2004). Wetland inventories suggest at least half of non-forested wetlands in the Willamette valley are agricultural (Daggett et al., 1998; Bernert et al., 1999; Taft and Haig, 2003). As a result of habitat loss and human persecution, 
four formerly breeding species are now completely extirpated in the Portland area: the blackcrowned night-heron, Lewis's woodpecker, yellow-billed cuckoo, and California condor. The former three species were heavily reliant on the once extensive floodplain marshland and forest that covered most of north Portland, including where the channelized Columbia Slough runs today through heavily industrial and otherwise built-up conditions (Hulse and Baker, 2002; The City of Portland, 2015). The pressures of rapid population growth on the scarce lowland habitat in the Willamette Valley and adjacent areas remain to this day. The population of the basin is expected to reach 4 million by mid-century (Schumaker et al., 2004).

It is difficult to determine optimal conditions at either a local and regional level in the Pacific Northwest as the environment has been enduring changes of varying scale since the Pleistocene, especially that driven by natural and anthropogenic fires, climate change, volcanic eruptions, glacial movement, and floods (Hessburg and Agee, 2003). Schumaker et al. (2004)'s modeling of species population trends in the Willamette valley suggests pre-European habitat in the region supported significantly greater populations for most measured species, save for introduced ones. Western meadowlark populations were as much as 300 fold higher in 1850 compared to 1990, though the authors admit to a lack of full interpretation of habitat patterns and patch size. The modeling also suggests relatively small population changes under future scenarios of development and conservation effort compared to 1990 (Schumaker et al., 2004).

Much research dealing with effects of habitat loss upon birds in the Pacific Northwest has specifically examined habitat fragmentation and alteration from timber practices. This has included a focus on experimental harvest and regeneration of forest in riparian areas in order to determine the impact of stream buffer narrowing on forest bird populations; although confusingly, such study often fails to distinguish habitat loss from fragmentation (Fahrig, 2003). Several species thrive in wide buffers in excess of 50 meters, but usually handle narrow strips of forest; where as additional species prefer narrower buffers, forest edge, and regenerative vegetation formed by clearing. Particularly high diversity is associated with broad-leaved canopy species and berry-baring woody species associated with riparian and other disturbances within these corridors; i.e. broadleaf maple, red alder, and salmonberry. Pearson and Manuwal's (2001) study revealed an increase in number of species present following adjacent clear-cut treatments around narrow $(<14 \mathrm{~m})$ riparian buffer zones, with declines in deciduous forest shrub and coniferous tree associates; but overall abundances did not change. This feeds into the narrative that disturbance, landscape heterogeneity, and the surrounding matrix feeds into diversity (Pearson and Manuwal, 2001; Fisher and Lindenmayer (2007). Wilson's warbler, Swainson's thrush, pacific wren, golden-crowned kinglet, black-throated gray warbler, hermit warbler, and pacific-slope flycatcher are among the most demanding species as far as extensive old-growth forest is concerned; whereas brown creepers and chestnut-backed chickadees can thrive in narrower residual stream buffers, so far as minimum forest size requirements $(>1.2$ HA) are met (Brown, 1985; Hagar, 1999). These latter birds however do best in unlogged sites, and tend to disappear in the narrowest buffers. Several reports note that riparian forests, including those along small headwater streams may prove to be of particular importance to such terrestrial passerines, along with warbling vireos, American robins, and rufus 
hummingbirds in comparison to upland forest habitat (Csuti et al, 1997, Hagar; 1999; Pearson and Manuwal, 2001).

It should be remembered that urban conditions invoke unique impacts to stream and riparian structure and community characteristics as a result of channeling and abundant surface runoff (Schueler, 1994; Finkenbine et al., 2000; Faulkner, 2004). The question remains then of the importance of these habitats within the urban setting.

Determination of correlations between ecosystem processes and species richness and assemblage have long been a major focus in landscape ecology (Rosenzweig, 1995); more recently, this focus has entered towns and cities (Fernandez-Juricic and Jokimaki, 2001). Not only does the degree of human construction and alteration affect native species assemblage, but so do elevation and vegetation composition and structure (Blair 1996, Acevedo 2008). Scientists like John Marzluff of the University of Washington have been giving particular focus on the effects of urbanization and the spread of suburbs in the Seattle area, as well as important factors that support diversity within heavily developed urban centers (Marzluff et al., 2001; Marzluff, 2005; Donnelly and Marzluff, 2006; Marzluff, 2008). Results are of course complex.

Gavareski (1976), in her examination of bird assemblages in Seattle's urban parks, states species richness and diversity is best determined by diversity in vegetation (especially in terms of height of foliage), and park size (marginally) rather than location of the park. Alterations to urban green spaces to create a relatively homogeneous landscape of cut grass and scattered trees do more to impact bird diversity and richness than any other urban factor. Similar studies of the urban landscape and remnant spaces considered potential bird refuges since this time have arrived at somewhat different results. For example, in a study of remnant forests and smaller urban green spaces in suburban Paris, Huste et Al. (2006) found significantly reduced species richness in the smaller green patches. The study found species richness in the urban patches to range from 13.60 to 47.95 species, with an average of 28 . By contrast, remaining large forests in the region contained 32.73 to 57.91 species (Huste et al., 2006). Discrepancies in richness between urban and outlying small and large patches may relate to the potential for fragmentation under urbanization to lead to greater contact with built urban landscapes and subsequent increased predation, should this exposure have a negative impact upon bird diversity (Marzluff, 2001: Jokimaki et Al., 2005: Ordeñana et al., 2010).

Small and isolated habitat patches may cause problems with species recruitment, as plants and less dispersive animals over-exploit, or become isolated from quality and abundant resources, and are unable to reach additional habitat (Faeth et al., 2011). Lack of certain predators can cause certain pestilence to ravage additional life in small habitat patches in certain areas (Speight et al., 1998; Adler and Tanner, 2013). Subsequent impacts to biodiversity on certain trophic levels may directly or indirectly affect birds of the area (Shochat et al., 2004). Studies on such complex fronts help to build our understanding. However, it is not always apparent which urban landscapes cater to a given species or which species will be able to take advantage of highly modified environments (Shochat 2004). Many factors, including food availability, nesting site security, and predator abundance all change with increased 
development, and these changes are not always easy to predict (Shochat 2004, Rutz 2008, Jokimäki 2000).

Newly formed suburban areas often add to overall species richness by way of introduction of regenerative forest habitat, as well as feeders, fields and other unshaded sites, pools, ponds, and artificial structures for nesting and roosting. Feeders in particular have been tied with increased numbers of house finches (Fisher et al. 1997; Nolan et al., 2001). Small levels of habitat fragmentation often do little to impact populations of birds closely associated with mature Pacific forest stands (Marzluff, 2005; Donnelly and Marzluff, 2006). Porter et al.'s (2001) analysis of intermediate disturbance and heterogeneity suggests local species diversity is maximized by the increased abundance of resources created by this human development. Marzluff (2005) builds off of this by demonstrating maximum local diversity at about $50 \%$ urban land cover. Hansen et al. (2005) reports species richness peaks in typical one-family housing subdivisions, and declines precipitously where developed land exceeds $80 \%$, as well as where forest covered the entire 1KM study site. Blewett and Marzluff's (2005) research showed fully forested study sites $1 \mathrm{~km}$ in area to contain no more than 15 species, with additional natural landscape heterogeneity increasing the richness number to 22 absent any urban land-cover.

The human/urban development factor seems to increase competitive interaction within a limited area of impact (Donnelly and Marzluff, 2006). An example of this in our area is the introduction of additional versatile species to the landscape that would otherwise be absent or rare, such as Bewick's wren (an inhabitant of dense scrubby vegetation associated with edge and relatively early successional conditions); various swallows that benefit from human structures for nesting, as well as significant forest openings; the black-capped chickadee; house finch; song sparrow; and some flycatchers (Marzluff, 2005). Along the forest/urban matrix interface, these birds in turn likely compete with such forest associates as Pacific wrens, chestnut-backed chickadees, Hammond's flycatchers (an uncommon species in Portland), and Pacific slope flycatchers, as they fill many of the same feeding guilds (Donnelly and Marzluff, 2006). Passage of time can result in a dramatic decline in species richness In cities and exurban sites in the Pacific Northwest due to the increased success of synanthropic species, and continued human modification to the landscape (35 species to 15 species on average over 80 years in one study from the Seattle area) (Hansen et al, 2005).

Human-associated birds may out compete, predate, or in the case of brown-headed cowbirds, parasitize nest broods of several susceptible species (Wilcove, 1985; Major et al., 1996; Donnelly and Marzluff, 2006). Such adaptable species have expanding ranges; and thus regional diversity is impacted at the expense of heterogeneity over vast areas of diverse geography (Marzluff, 2005). Lack of success of fledglings to survive or become reproductive may be a factor in the declines of forest associated species (Hansen et al., 2005).

In contrast to so many negative impacts, human activity, including severe landscape modification, has long benefited some bird communities by way of encouraging the spread of regenerative and fire-dependent habitat. With the colonization of the Pacific Northwest by white settlers, some distinct habitats have become rare and nearly extirpated, along with the birds they served (Schumaker et al., 2003). This remains a concern; but human activity 
continues to provide rich habitat for birds and other life, both through construction of artifices, and conservation and restoration activities. Blewett and Marzluff (2005) even demonstrate that remaining forest patches within towns 60-80 years in age bore more snags in late decay compared to patches in younger towns of 2-20 years, thus suggesting that passage of time can benefit several cavity nesters, such as woodpeckers, chickadees, nuthatches, and brown creepers. In fact, in Portland we can see many exceptions to trends plotted out by Hansen, or Donnelly and Marzluff, and other published works that point towards a decline in richness towards urban cores. Most urban landscapes are regularly built around and upon bottomland soils and the shores of large water bodies used for shipping, irrigation, drinking water, and other services (World Resources Institute, 1994; Small and Kohen, 2004; Marzluff, 2005). Studies reveal the continued importance of residual habitat found in such cityscapes, along with the lush cultivated and manicured properties filling in open substrates within and upon urban spaces (Ohmart, 1994; Schaefer, 1994). Urbania may also provide abundant food and shelter for birds that otherwise face pressure from agricultural activities on the city fringes. Sometimes such anthropogenic and heavily modified, pressured, or confined city habitats can be more species rich than less populated or impacted landscapes well on the outskirts of town (Knopf et al., 1988; Naiman et al., 1993; Rottenborn, 1999). Predatory birds in particular are commonly less persecuted in cities compared to the countryside and additional birds can benefit from artificial shelter, supplemental feeding, and ornamental plants in town (Atchison and Rodewald, 2006; Hruska et al., 2008; Evans et al., 2009). Stream water phosphorus and nitrogen pollution is also often greater in areas of row-crop agriculture compared with cityscapes (Smith and Schaefer, 1992; Faulkner, 2004).

Many birds positively associate with the wetland that exists primarily within the confines of heavy urban development, though certainly not all. Thus, the author predicts bird species communities to relate most strongly with contrasting factors along rural to urban and forest/dry/low intensity development to wetland and heavily built bottomland trends in the environment. Wetland dominated natural habitats in the lowlands, which interact profoundly with built-upon land and other habitat in the matrix, are expected to support the greatest richness; though this may depend on the size of residual natural habitat and other particulars. The following sections will explore this and test this assessment, examine the fine points of urban habitat community structure and patterns within the greater Portland metropolitan landscape, and finally assess the implications for purposes of diversity and rare-species conservation. This will be accomplished by way of comparison of site species assemblages, and relating the similarities and differences with environmental factors seen around the sites in question (Faith et al. 1987).

\section{Methods}

\section{Data Source and Preparation}

The data in the study comes to us courtesy of the collections of Portland Environmental Services, based on point counts collected upon 160 different sites on the Services restoration land within Portland and adjacent unincorporated communities. It consisted of 16,000 bird sightings made in a total of 998 visits over the course of eight years. 28 surveyors collected this 
information, acting as individuals or in groups of up to three members in morning visits prior to 10:00AM, mostly in the spring and early summer. A wide variety of habitat/land-use types were included in these sites.

This data was reduced to three breeding season visits per site (summed within sites to form the spreadsheet compatible with an environmental matrix sheet). The data was further reduced due to the unfortunate reality that not all sites bore three collection dates at all or during the period of the year considered appropriate, from the last week of May to the first week in July. This was determined to represent a time span over which birds would be generally settled for establishing territory and nesting, and thus most vocal and readily detected. The majority of sites' data already conformed to this standard. It should give an accurate picture of the assemblage of avian species that do breed in the inner Portland metropolitan area, rather than simple migratory stopovers or wanderers (See Appendix for a list of scientific names, common names, and standard four letter codes used in the matrix).

Only one years' worth of data was used as this was the limit of collection for most sites. Five sites collections lacked GPS location designation, and thus were removed (three species were found only in these sites, and were thus excluded). Some additional sites had less than three visits worth of survey information. The subsequent species matrix contained data for 151 sites shown in columns preceding the number of detections if any for each species. Once all species that did not show up at all in the data were removed, 95 remained making up the columns, along with eight columns for unidentified representatives of bird families/orders. While this comprehensive matrix will be referenced in discussions below, for purposes of analysis, reduced species matrices were used with low-incidence species eliminated in order for there to be less nebulous results. More will be stated about this below; but essentially three species matrices will be referenced: one with 82 species, plus six unidentified bird categories, one with 66 species, plus a column for unclassified swallows, and a matrix with 34 species. It seemed relatively harmless to include the uncertain species columns, as they rarely overlapped with their respective taxonomic groups at individual sites.

\section{GIS and Environmental Matrix}

The species matrix was combined with an environmental matrix containing all sites maintained in this Species datasheet, as well as measurements pertaining to different aspects of the landscape. Note that by landscape, I refer to assemblages of habitats within a given site's buffer zone or vicinity of the study region. Total area and Percentages of land-use/land-cover types, as well as average elevation were tabulated using ESRI ArcMap 10.1's buffer operation, which created a perfect two-dimensional wring around the point location with a radius of $500 \mathrm{~m}$. This radius was arbitrary, though it is speculated that results would prove similar with smaller buffer zones. Some ornithologists have utilized $500 \mathrm{~m}$ buffers, and the aim in the case of this study was to include landscapes adjacent to that existing at the central point of the data collection.

Land cover types included coarse $\left(30 \mathrm{~m}^{\wedge} 2\right)$ resolution information from the 2011 National Land Classification Database (NLCD) and fine scale $\left(1 \mathrm{~m}^{\wedge} 2\right)$ measurements via first 
return 2007 Lidar data from Metro GIS. Much of the specific land cover classifications, such as low, medium and high intensity development, as well as deciduous, mixed, and evergreen/ coniferous forest, were at a coarse scale and thus can be said to be less accurate in terms of area and distribution than fine resolution first return LIDAR data; but were valued equally through most of the project. The fine resolution LIDAR data information (mean elevation, canopy class area, and impervious surface class area) was not without shortcomings, as underlying vegetation here was ignored.

The environmental matrix contained three distance measurements from the individual sites: distance from natural areas (recognized land set aside for conservation purposes), distance from schools, and distance from gardens, all based on Portland Parks and Recreation data. Mean elevation within each buffer was also calculated and included. The land-cover area, and distance measurements are represented in feet for finer definition, whereas elevation is in meters.

\section{Calculations:}

All additional calculations were executed using R 3.2.0. A Species diversity operation was executed using the 82 species reduced matrix. The process provided a quick reference of species richness, Shannon diversity and evenness (not examined in this paper), and Simpson evenness and diversity (not evaluated in this paper) for each site. Both the environmental matrix and diversity were utilized in a series of Pearson's correlations with the species matrix and between the various environment-based statistics in order to gain perspective on the processes at play (See the following section). This was followed by the use of Bray-Curtis Dissimilarity with the ENVFIT Algorithm of the R Vegan package and Non-Metric MultiDimensional Scaling (NMDS) processes, which resulted in an image of important variables affecting each site's community sample, and the trends these communities follow in relation to one another and the environmental variables. Following this, three groups or sub-categories of sites were formed intuitively, but otherwise arbitrarily based on the trends discerned, entitled "Wetland", "Built", and "Forest".

An indicator species process was conducted in $\mathrm{R}$ to help define these groups and their importance. Examples of bird communities and environmental conditions of site buffer areas within each group were assessed with Google Earth imaging, and subsequent findings are referenced in the discussion. Note that the moderate sized (66 species) matrix was used for purposes of ENVFIT and NMDS, given the greater ENVFIT values, which were nearly equal to those of the smallest species matrix; but elsewhere, the 82 species matrix was assessed for a wider perspective on community assemblages; although some effort is made to point out the relative scarcities. Elimination of uncommon species for purposes of multivariate statistical analysis is commonly considered prudent due to elimination of anomalies and additional gray areas (Poos and Jackson, 2011). What follows are further details on the processes.

Pearson correlation provided some additional perspective on the relationship between species assemblage and land-cover values within the landscape of the study. The first path in the project was that of simple Pearson correlation analysis among the geographic variables, or 
land use cover types (See Environmental Matrix). Added to the matrix for this purpose, and hence for inclusion in the correlation study, was simple richness (the number of species at each study station. This made for a total of 47 variables in the matrix, as most land use variables existed in terms of total land area in square feet, and percent cover-essentially causing much near-duplication. Once the correlation table was generated in a CSV file using R, results for each variable in the form of $R$ values were copied and pasted into a new spreadsheet next to lists of variable names, until each variable and its associated $R$ values covered two columns a piece. This was done for the sake of comparison of values, as well as for ease of reading. $R$ values for each column pair were then ordered from least to greatest in order for facile determination of correlates.

The Environmental Fit procedure allows for the determination of important environmental factors effecting both the species and environmental matrix in the study. This is executed by plotting the relationships between these environmental matrices using Bray-Curtis Dissimilarity and the species compositions' relationships with each environmental factor. Each environmental factor or land cover type was plotted as a biplot vector using scaled relationships of these environmental values. Insignificant vectors were excluded from the biplot analysis.

Three different versions of the species matrix were put through the ENVFIT process: one with all species appearing at least three times; the second with all species appearing at least eight times; the third with species appearing fifty times or more. Each resulting output table contained several significant variables (12 for the first matrix, and 23 for the Second and Third Matrices); the second output biplot was used (see Figure 1), due to the high $\mathrm{R}$ values and similarity with that of the third reduced matrix.

Non-Metric Multi-Dimensional Scaling (NMDS) defined the relationships between all sites over a biplot. A two-dimensional scaling distance chart, with a Cartesian graph, was developed to simplify the many dimensions of the plot and reveal general trends of the site distribution. The chart illustrates how sites align, whether they be apparently bunched into groups or related with similar distance according to a trend. Since the sites appear linearly distributed, additional cluster analysis was deemed unnecessary. The NMDS biplot was overlain atop the ENVFIT graph. Based on the resulting trend of the sites over ENVFIT, three groups of sites were formed using environmental matrix-based rankings the author felt would be meaningful (see results).

The limitations of the study made it difficult to distinguish the three clusters from one another. Specific plant species indicators for example were lacking in the data. Nevertheless, it was decided avian indicator species would be helpful in this regard, and would be informative in terms of landscape significance and implications for bird populations and conservation. Indicator Species Analysis was conducted with each reduced species matrix. Examination of some sites from each cluster using Google Earth imaging, and the species communities of these sites as plotted in the minimally reduced species matrix gave additional perspective on the importance of these indicator species in terms of deciphering habitat-species relationships. The process provides an indicator value ranging from zero to one to each species deemed a 
significant indicator $(p=<0.05)$. The indicator value is based on the statistical likelihood that a species prefers a particular group. This is discerned based on the abundance of a given species, and the proportions of its sightings in a given group. Very rare or broadly/opaquely distributed birds do not receive a significant indicator species value. Species may have a low indicator value, and yet be accepted as a valid indicator, especially when abundance is low. The results provide a useful sense of the diversity and typical composition of sites within a group. In turn, the value of a group's conditions to particular birds and bird diversity can be assessed for commentary.

\section{Results}

R Values:

Results here do not comprehensively include correlations calculated with individual bird species; though important examples of such results are exhibited later. Certain species tend to become proportionately more abundant as species variety increased. $R$ values inform us about land use variables that associate strongly with richness.

The proportion of developed land had the highest positive correlation with species richness $(R=0.426)$, followed by woody wetlands $(R=0.332)$, emergent wetlands $(R=0.323)$, croplands $(R=0.293)$, pasture $(R=0.278)$, medium-intensity development $(R=0.269)$, distance from natural areas $(R=0.256)$, and shrubby and grassy vegetation structures $(R=0.199)$. When it came to negative correlates with richness, of most significance was Mixed forest $(R=-0.389)$, thence general canopy cover $(R=-0.379)$, Deciduous forest $(R=-0.307)$, Elevation $(R=-0.303)$, and Evergreen forest $(R=-0.266)$. As portrayed in the ENVFIT section below, similar trends from forest to high-intensity development along a high to low elevation gradient exists in terms of additional scaling analysis.

I evaluated general developed, or built land; the highest correlates with this variable were: Low-intensity development $(0.47)$, pasture $(R=0.443)$, Medium intensity development $(R$ $=0.44)$, developed open space $(R=0.378)$, Street density $(R=0.364)$, area cover of buildings $(R$ $=0.333)$, Shrub/grass $(R=0.3)$, Woody Wetlands $(R=0.254)$, crop lands $(R=0.238)$, and emergent wetlands $(R=0.188)$. On the negative side of the developed land vector, there is Mixed Forest $(R=-0.656)$, total canopy $(-0.629)$, Deciduous forest $(-0.465)$, Evergreen forest ($0.462)$, and distance from schools (-0.416). While the different significant values here are far from the same as those in richness; with additional associated land-uses playing a significant part, and ranked correlations being in a different order, they are fairly similar, with values like streets, low-intensity development, and developed open space now playing a significantly positive roll.

Examination of the second most valuable factor to richness (woody wetlands, an important natural feature of the Willamette lowlands) confirms notable association with additional important vegetated landscapes: emergent wetlands (0.739), crops (0.467), pasture (0.418), and shrub/grass (0.178). High-intensity development and parking lot density appear with woody wetland as a positive correlate ( 0.277 and 0.275 respectively). These results, 
combined with Google Earth imaging, and ENVFIT all give perspective on the landscape arrangement throughout the Portland study area.

\section{ENVFIT Results}

Using the best ENVFIT results from the reduced Species matrix, only three values proved insignificant. The average $R$ value per significant variable was 0.357 ( $S D=0.18)$. The most significant variable was canopy cover (a $1 \mathrm{~m}^{\wedge} 2$ resolution fine scale variable-- $\mathrm{R}=0.743, \mathrm{P}=0.001$ ). The three insignificant variables were Water per $30 \mathrm{~m}^{\wedge} 2$, $(R=0.034, P=0.071)$ Grassland $(R=0.024, P=0.193)$, and Developed Open Space $(R=0.004, P=0.77)$. As stated, the moderately reduced matrix was used as the source of the highest and thus best numerical values, and the subsequent plot generated from ENVFIT. Vectors here pointed in all directions across the biplot, with some conspicuous trends.

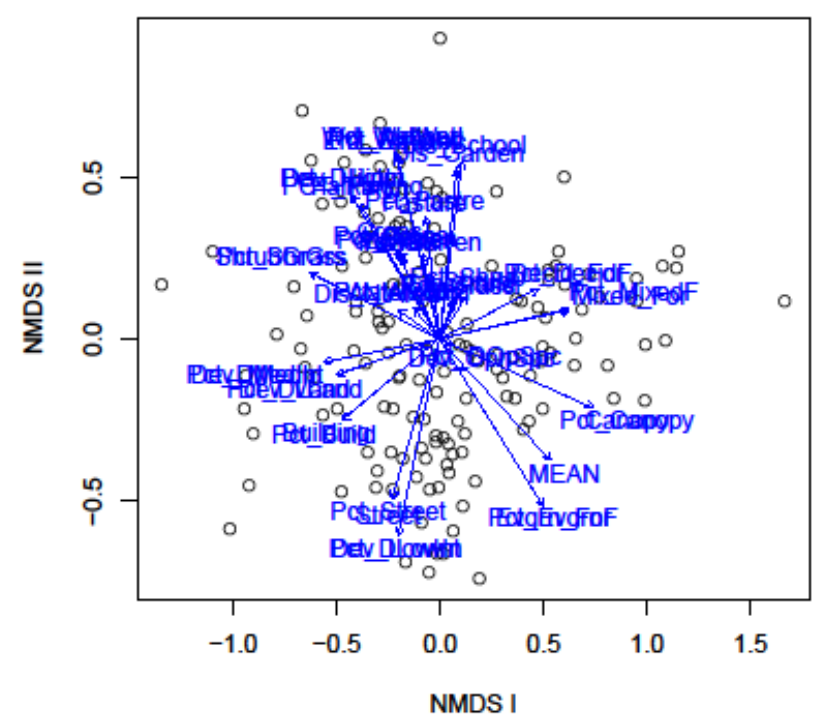

Figure 1: ENVFIT Plot [Points over the lines indicate individual sites.]

NMDS and Clustering Results:

The NMDS distribution ran roughly linearly from high elevation forest, through less forested and sometimes wetland-containing suburban areas, to heavily urbanized lowlands within significantly sized restoration and conservation areas. As described in the methods section of this paper, clusters could not be reasonably generated through algorithmic methods and Pruned-Tree output selection using any $\mathrm{R}$ program package. The relatively linear distribution of the sites on the NMDS plot meant that results of such methods might not be highly logical or explicable; and arbitrary selection of clusters by hand would be at least as effective, but open to questions and future reconfiguration. Due to the uneven distribution of sites upon the general landscape trend, it became evident groups would not be equal in size. It was decided the three categories would be "Forest", where the majority (>80\%) of the 
landscape was covered by a combination of mixed, deciduous, and evergreen forest; "Built", in which a combination of Intense, Moderate, and light development land predominated, with total wetland falling below $5 \%$ cover and being less than total development; and "Wetland" where combined emergent wetland, woody wetlands, and open water acceded $5 \%$. The decisions were based on qualitative glances at the data along with Google Earth images, and attempts at generating the most distinct of groups. Wetlands in the study were small and rarely came close to dominating the landscape. The 80 and five percent threshold were seen as sufficient for segregating sites with the most significant forests and wetlands respectively in the study, although the issue was not pursued with additional statistical rigger. In general, only the smallest of wetlands occurred wherever coarse scale forest registered. Due to the location of most wetlands being amidst low-lying, heavily urban landscapes, it was recognized the Wet and Built site groupings would often have much more in common than with Forest. Built represented the greatest number of sites with 67 . The land was largely suburban, as suggested by the ENVFIT; with dominant landscapes being either development, or in rare cases low vegetation and agricultural cover.

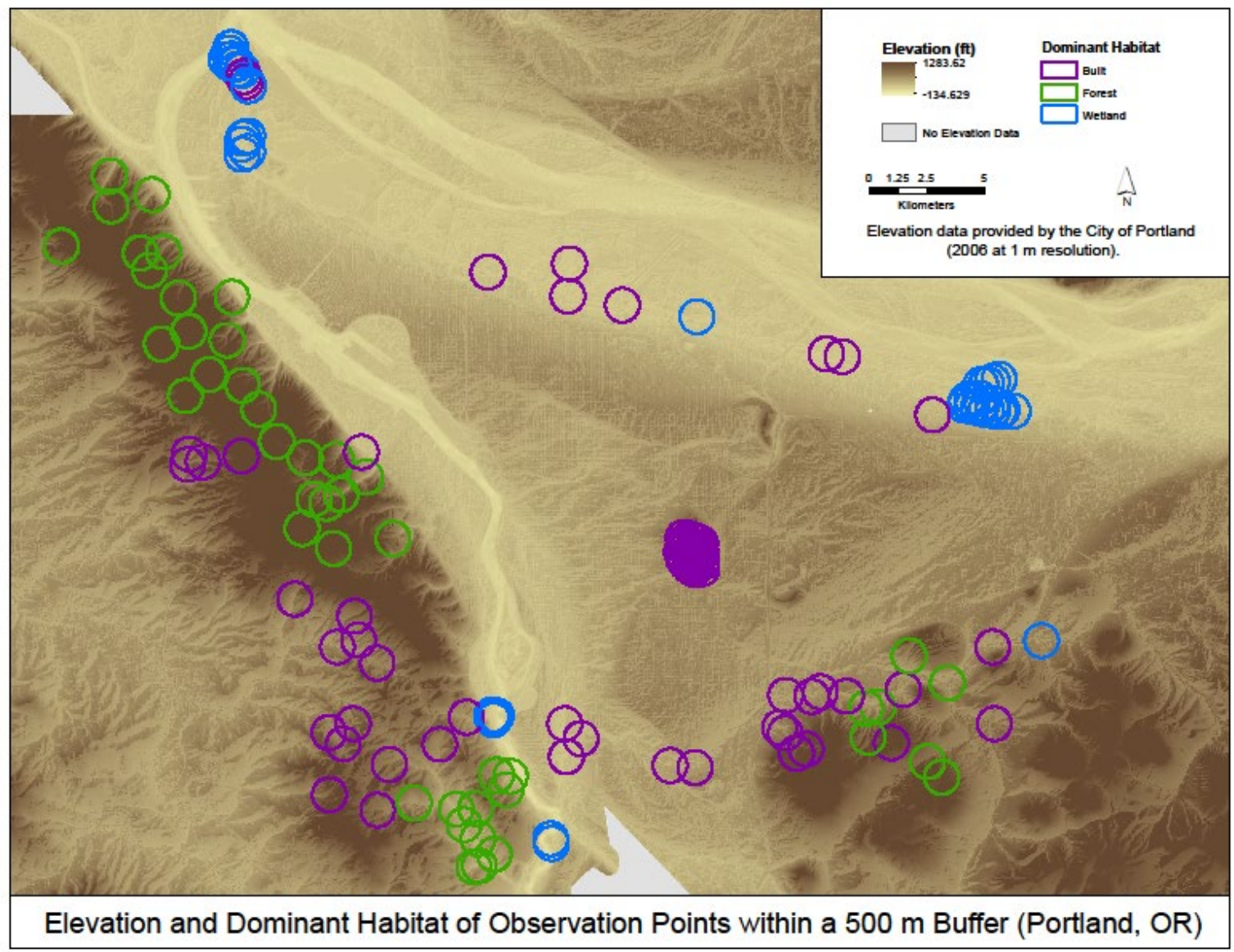

Figure 2: Land Cover.pdf 2 Observation Points with 500 m Buffer 01.252 .55 Kilometers Data provided by the National Land Cover Database (2011 at $30 \mathrm{~m}$ resolution). Overlapping buffers merged at Mt. Tabor, Big Four, and Slough Confluence project 45 Land Cover of Observation Points within a $500 \mathrm{~m}$ Buffer (Portland, OR) 
The Forest group contained 44 sites, each of which featured significant amounts of each forest type. Non-forested areas within this group were usually suburban in nature-a fact reinforced by Google Earth images. Wetlands were usually absent on a coarse scale; though some analysis of species composition revealed small presents of wetland and riparian birds-a fact likely tied with the presents of low-level streams. Similar than either group would be to Forest. This was in evidence during the process of Finally, the Wetland group contained just 40 sites. Wetlands varied in size and type, with some such as those at Elk Island being dominated by open water of the Willamette River. Naturally, woody and emergent wetlands were found at generally slightly higher elevations than those with riverine open water; but the wetlands usually fell along highlevel waterways of conservation significance such as the Columbia Slough.

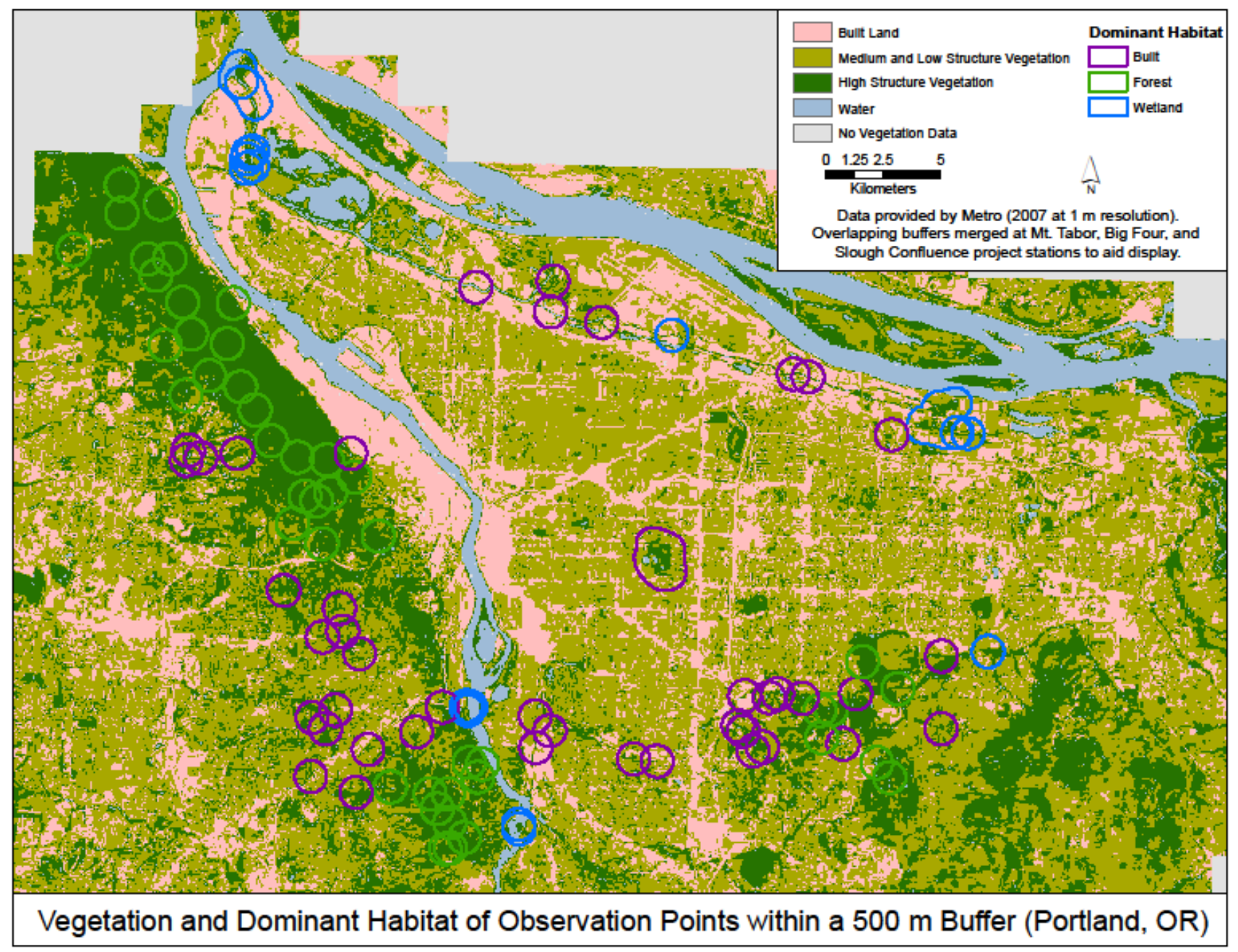

Figure 3. Vegetation and dominant habitat of observation points. 


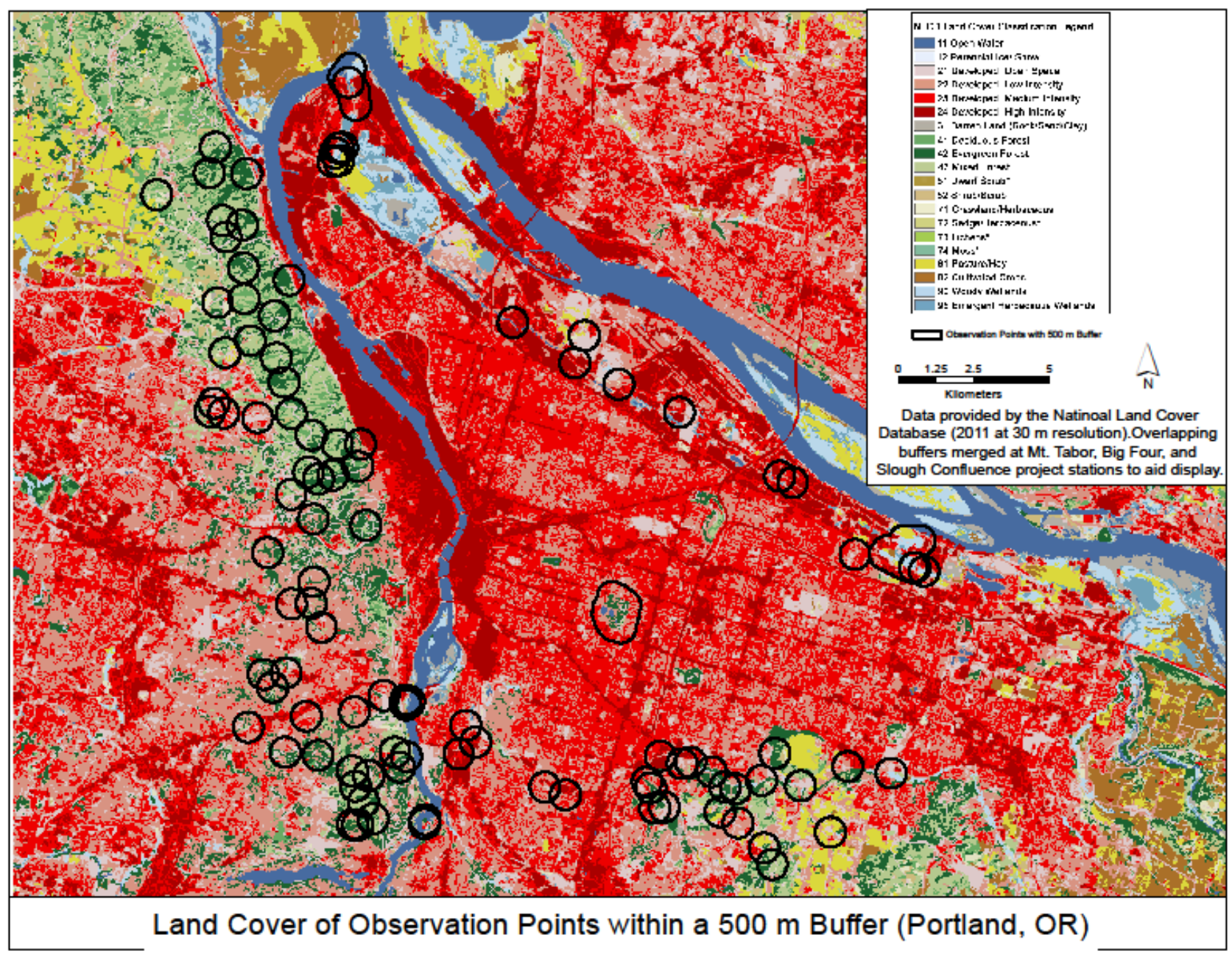

Figure 4: Land cover of observation points. Elevation (ft) 1283.62 -134.629, Dominant Habitat, Built, Forest, Wetland. Elevation data provided by the City of Portland (2006 at $1 \mathrm{~m}$ resolution). 01.252 .55 Kilometers Elevation and Dominant Habitat of Observation Points within a $500 \mathrm{~m}$ Buffer (Portland, OR) Data provided by Metro (2007 at $1 \mathrm{~m}$ resolution)

Results of Indicator Species Analysis:

The results did not vary significantly, with the principal difference being increased number of indicator species with less matrix reduction. No species switched groups according to the matrix used; although the synanthropic house sparrow only showed up (as a Built indicator) in the indicator output from the moderately reduced species matrix. The output listed, along with the names of the species, Indicator Values (INDVAL), P values (P less than 0.05 species were shown), Frequency (Number of sites where a species occurred), and additional comments where applicable. The figure below shows the Indicator Species output from the least reduced species matrix. 
Table 5. Indicator Species Output

\begin{tabular}{|c|c|c|c|c|c|}
\hline \multicolumn{6}{|l|}{ Built Indicators } \\
\hline Species & ndval & P Value & Frequency & & \multirow[t]{2}{*}{ Comments } \\
\hline American Crow & 0.523379 & 0.001 & & 96 & \\
\hline House Finch & 0.473244 & 0.001 & & 68 & \\
\hline Lesser Goldfinch & 0.37928 & 0.001 & & 44 & \\
\hline Northern Flicker & 0.378482 & 0.001 & & 73 & \\
\hline Anna's Hummingbird & 0.343448 & 0.001 & & 42 & \\
\hline Dark-eyed Junco & 0.310011 & 0.001 & & 40 & \\
\hline Red-Breasted Nuthatch & 0.28463 & 0.001 & & 36 & \\
\hline Bewick's Wren & 0.274121 & 0.029 & & 69 & \\
\hline Western Tanager & 0.270778 & 0.012 & & 61 & \\
\hline Pine Siskin & 0.228616 & 0.001 & & 22 & \\
\hline Mallard & 0.204897 & 0.015 & & 40 & \\
\hline Hutton's Vireo & 0.14511 & 0.007 & & 14 & \\
\hline Townsend's Warbler & 0.144609 & 0.021 & & 21 & \\
\hline Evening Grosbeak & 0.127985 & 0.049 & & 19 & \\
\hline House Sparrow & 0.08639 & 0.044 & & 8 & Moderately Reduced Matrix Only \\
\hline \multicolumn{6}{|l|}{ Forest Indicators } \\
\hline Species & indval & P Value & Frequency & & Comments \\
\hline Pacific Wren & 0.861045 & & 01 & 48 & \\
\hline Pacific Slope Flycatcher & 0.629883 & & 01 & 68 & \\
\hline Wilson's Warbler & 0.487697 & & 001 & 75 & \\
\hline Swainson's Thrush & 0.442859 & & 01 & 77 & \\
\hline Chestnut-Backed Chickadee & 0.245886 & & 04 & 41 & \\
\hline Hairy Woodpecker & 0.18595 & & 01 & 10 & \\
\hline Purple Finch & 0.184366 & & 01 & 11 & \\
\hline Pileated Woodpecker & 0.115897 & & 19 & 11 & \\
\hline Unidentified Warbler & 0.113636 & & 04 & 5 & Least Reduced Matrix Only \\
\hline \multicolumn{6}{|l|}{ Wetland Indicators } \\
\hline Species & indval & Value & Frequency & Com & ments \\
\hline Western Wood-Pewee & 0.645382 & 0.001 & 56 & & \\
\hline Brown-Headed Cowbird & 0.621281 & 0.001 & 64 & & \\
\hline Yellow Warbler & 0.595039 & 0.001 & 31 & & \\
\hline Cedar Waxwing & 0.511241 & 0.001 & 56 & & \\
\hline Willow Flycatcher & 0.493824 & 0.001 & 30 & & \\
\hline Spotted Towhee & 0.419772 & 0.001 & 119 & & \\
\hline Song Sparrow & 0.379064 & 0.011 & 140 & & \\
\hline Black-Capped Chickadee & 0.349884 & 0.006 & 98 & & \\
\hline Warbling Vireo & 0.306479 & 0.001 & 46 & & \\
\hline
\end{tabular}




\begin{tabular}{|c|c|c|c|c|}
\hline Downey Woodpecker & 0.302074 & 0.001 & 33 & \\
\hline Orange-Crowned Warbler & 0.289011 & 0.001 & 26 & \\
\hline Brown Creeper & 0.283965 & 0.012 & 64 & \\
\hline Tree Swallow & 0.275622 & 0.001 & 15 & \\
\hline Canada Goose & 0.261227 & 0.001 & 22 & \\
\hline Unidentified Swallow & 0.235882 & 0.001 & 15 & \\
\hline European Starling & 0.234287 & 0.026 & 48 & \\
\hline Common Yellowthroat & 0.224606 & 0.001 & 17 & \\
\hline Wood Duck & 0.215121 & 0.001 & 10 & \\
\hline Western Scrub-Jay & 0.1927 & 0.013 & 32 & \\
\hline Bushtit & 0.183394 & 0.032 & 37 & \\
\hline Red-Winged Blackbird & 0.155642 & 0.002 & 10 & \\
\hline Great Blue Heron & 0.153346 & 0.007 & 18 & \\
\hline White-Crowned Sparrow & 0.140139 & 0.001 & 10 & \\
\hline Bullock's Oriole & 0.125 & 0.001 & 5 & Least Reduced Matrix Only \\
\hline House Wren & 0.118655 & 0.002 & 6 & \\
\hline Rufous Hummingbird & 0.117367 & 0.02 & 14 & \\
\hline Unidentified Hummingbird & 0.091667 & 0.016 & 7 & Least Reduced Matrix Only \\
\hline Great Horned Owl & 0.089413 & 0.019 & 7 & \\
\hline Bald Eagle & 0.087013 & 0.014 & 5 & Least Reduced Matrix Only \\
\hline Unidentified Duck & 0.075 & 0.011 & 3 & Least Reduced Matrix Only \\
\hline
\end{tabular}

Indicator Species Result Analysis

As predicted, a number of Built species are significantly correlated with human development according to Pearson analysis of the data, as well as secondary literature. Birds such as crows, house finches, and Anna's hummingbirds are well known urban or suburban associates, with increased populations and range expansion tied to the built environment and environmental alteration, as well as ornamental plants (La Sorte and Thompson, 2008). Mallards (a wading bird necessarily tied with habitats with standing water) is another Built indicator. This may be due to the bird's synanthropic nature, as well as its acceptance of small bodies of water, and use of built and manicured environs adjacent to water (Poole and Gill, 2002). Curiously, the house sparrow, an obligate of human dwellings and an alien species, only shows up as an indicator for the intermediate reduction matrix, where it is the least significant of the birds listed. This appears due to the bird's relative scarcity, as well as use of suburban and urban conditions adjacent to large forests and wetlands. Red-breasted nuthatch, pine siskin, lesser goldfinch, western tanager, dark-eyed junco, Townsend's warbler, and evening grosbeak display a significant Pearson correlation with evergreen forest within the study. This likely suggests a close relationship between upland suburban sites and coniferous forest as indicated by ENVFIT. In fact, only the mallard showed a positive correlation with high-intensity development; and only three additional species (Bewick's wren, Northern flicker, and American crow showed no correlation with high-intensity development). 
As per Forest, Pacific wren, Pacific Slope flycatcher, Wilson's warbler, Swainson's thrush, chestnut-backed chickadee, hairy woodpecker, purple finch, and Pileated woodpecker are well known forest species. The Pacific wren, while among the most abundant birds in the study, has a moderate frequency of 48 among the indicators (Mean=39, SD=30.81). Leading indicator species of the other groups are far more widespread, but have comparably weaker INDVALs. In addition, the Indicator Species with the least reduced species matrix lists unidentified warbler(s) (XXWA--likely hermit warbler, Townsend's warbler, or black-throated gray warbler).

Several additional species bare significant Pearson's correlations with coniferous forests (a value less abundant in Forest than other canopy types): band-tailed pigeon, black-throated gray warbler, olive-sided flycatcher, and Steller's jay. Three of these birds had a significant correlation with overall canopy cover (a fine scale matrix): Steller's jay, band-tailed pigeon, and black-throated gray warbler. In addition, the black-headed grosbeak (a very common bird in the study, and a known associate of riparian woodlands) correlates strongly with mixed forest (Lehmkuhl et al., 2007). The black-headed grosbeak was the only non-Built species with a positive correlation both with a forest-related variable and species richness. non-indicative forest birds, only the olive-sided flycatcher and black-throated gray warbler lacked a strong correlation with elevation.

As for Wetland, the Indicator Species process rendered 26 species, plus unidentified swallows with a frequency of 15 in total (four swallows occur with acceptable numbers for the study). Six of the wetland indicators did not correlate with richness: Canada goose, blackcapped chickadee, brown creeper, great horned owl, house wren, and white-crowned sparrow. Only four indicators do not show any correlation with human development: the Canada goose, which is a well-known synanthropic bird in Portland and elsewhere (Poole and Gill, 2002), the warbling vireo, the less common house wren; and the uncommon great horned owl, which may be a heavily under-accounted-for bird as only diurnal sightings were collected for the data.

Only two of the three wading birds present as indicator species in the Wetland group in Portland evidently favor vegetated wetlands over open water. The Canada goose is strongly correlated with open water at a fine scale but only a marginally significant correlation with emergent wetlands and no correlation with woody wetlands. The great blue herons showed a slightly better Pearson correlation with emergent wetlands and woody wetlands; but it was more strongly tied with open water. Contrastingly, the less common wood duck had no significant correlation with open water, but was strongly connected to emergent wetland and woody wetland.

\section{Discussion}

Important relationships Between Citywide Geography, Habitat Distribution and Related Bird Communities

This examination sought to determine the effects of urbanization on bird community structure in Portland using Geographic Information Systems, data collected from point counts on land restoration sites, and mathematical processes, including Bray-Curtis Dissimilarity and Non-Metric Multidimensional Scaling. It was predicted from the outset that high elevation 
areas on the perimeter of heavily populated and urbanized reaches of Portland would support forest associated species, and species most demanding of unbroken habitat, whereas low lying areas would support greater numbers of synanthropic species, as well as wetland species where such habitat remained along the cities large, slow flowing/stagnant, and flood-prone water courses. It was not speculated what effects the rural to urban gradients would have on species richness and diversity as literature indicates complex answers to this question.

Ultimately, trends in species communities did indeed follow a largely elevation defined trend from the rural outskirts, through moderate elevation, largely suburban conditions, to the urban inner core of Portland. This trend included Changes in the abundance of individual species according to habitat correlations. The bird compositions followed trends in habitat similar to what was predicted by earlier experiments from the author and scrutiny of the Portland landscape. The habitat trend can be further generalized as a grading from a largely mesic and expansive upland forest, to a more suburban or agricultural mid-elevation landscape with relatively small wetland zones and forest areas, to larger wetlands surrounded by intense land modification and typical inner-city structures. Specific factors such as better defined landcover types (deciduous and mixed forest, woody and emergent wetlands etc.), as well as relatively rare features such as crop land have an effect.

Built Lands

It may be predicted that Built habitat has the fewest number of indicator species as a consequence of the great number of sites and the relatively wide diversity of landscapes found in the group, and significant overlap of habitat conditions with the Forest and Wetland groups. In fact a moderate number of indicator species (15) are representative here, though the three best indicators have lower INDVALs than those of the other two groups, a fact that may suggest a degree of habitat generalization, as well as additional use of the development associated with the other groups (low and moderate in Forest, and high for Wetland).

Another interesting aspect of the list of Built's indicators is the presence of non-synanthropic species, including those correlated with or known to prefer other habitats, especially coniferous forest. Most such species may thus be better considered forest species, all be it those at least somewhat tolerant of suburban development, and possibly better associated with small to moderate sized patches of forest than unbroken forests that fill the majority of the buffer zones (Exact trends were not plotted). As few birds are not negatively associated with high-intensity development, there may instead be a degree of sensitivity to human development and loss of forest and other habitat. Unlike the Forest indicators, all but the Western tanager are positively correlated with species richness. As with Forest, all are positively associated with elevation.

\section{Forest Group}

The Forest group has the fewest indicator species (8), though each one is well known as a forest dweller. It is unfortunate that there is/are unidentified warbler species here. The three species surmised as possibilities are known forest dwelling species with fairly similar plumage and songs; though the hermit warbler was excluded from all but the least reduced of the 
species matrices due to scarcity. Townsend's warbler and hermit warbler are known to hybridize in Washington and Oregon where their ranges overlap (Wright et al., 1998). The purple finch and pileated woodpeckers, while uncommon in the study, are known to be species of concern that have recolonized and increased in abundance in forest park as forests there have matured (Deschler et al., 2012); though purple finches are also known to inhabit scrubby habitat, and in this study correlate more strongly with this land cover type than it does any forest type (Lehmkuhl et al., 2007; Deschler et al., 2012).

Notable is the fact many species (both common and moderately scarce) that did not show up as indicator species are also well known either as forest guild species, or as habitat generalists that include forest among the environs they readily utilize. The

Golden-crowned kinglet, a bird understood to be a species of forest interiors, was relatively uncommon in the study, and did not have a strong correlation with any habitat type discussed (Hagar, 1999). The American robin is often ubiquitous in shaded city streets and manicured parks with mowed grass, but is also known to thrive under forest situations (Pearson and Manuwal, 2001). Additional forest species like the varied thrush, red crossbill and common raven were taken out of the moderate and highly reduced species matrices due to overall scarcity (Adkisson, 1996, Hagar, 1999, Marzluff, 2005).

Relationships between species and consequential effects on diversity can't be determined from this study's methods; but in spite of high indicator values for a few birds, the Forest group contains sites with relatively low diversity on average. A large subset of the Forest indicators represents birds with quite high abundance (Pacific wren, Pacific slope flycatcher, and Swainson's thrush). Some non-indicative forest species such as Steller's jay and blackheaded grosbeak are very abundant in the data; and indicators from the other groups, like song sparrow are abundant where appropriate conditions as riparian and edge vegetation are present. Relatively few of the scarcely seen birds in the study were detected in any of the Forest sites. On the other hand, the abundant pacific wren and Pacific slope flycatcher, were the most habitat-exclusive of birds in the study.

Forests that include features such as clearings and snags are well known to contain high diversity compared with other forest situations (McGarigal and McComb, 1995, Chambers et al., 1999). Thus the lack of rare species in the forest group, along with representatives from the other groups may be a consequence of the lack of snags and certain disturbances. Thus Forest sites may not consistently support the needs of potential Forest species.

Among Wetland species is a mix of synanthropic birds, birds of forest edge and early regenerative woody vegetation; riparian species, woodland/arboreal species, and purely wetland species; as well as birds common to more than one such guild. Wetland-related disturbance and soil does support a unique broadleaf woodland configuration, readily supporting forest-associated birds (ODFW, 2015). In fact, wading birds and other species well known to be sensitive denizens of wetlands are generally among the lowest ranking of the Wetland indicators (Poole and Gill, 2002). This may be a result of a number of factors, including diversity of distinct habitat types, such as significant distinction between open water and well 
vegetated wetlands; the state of wetland restoration, including the planting of native vegetation; size of wetlands and the fact that many of the present wetlands only consume a small portion of the buffered area; the importance or use of the ecotones and wetlands associated with a particularly high diversity of avian species; the prominent presence of highintensity development; and additional facets difficult to analyze from a distance like mudflats and tidal pools that support a unique assemblage within the group. Likely all these factors come into play. Most species here are correlated with high richness; though as mentioned, specific wetland types play a large role in the exact bird community structure. A few of the Wetlands species do not appear correlated with richness, possibly due to habitat homogeneity within these sites, the relative scarcity of three of the species, and tolerance or preference for degraded and low-diversity habitats throughout the Portland study area.

The three highest ranked indicators are known associates of open low-stature vegetation and forest clearing/fragmentation (Hagar, 1999, Lehmkuhl et al., 2007), and in addition correlate strongly in the Pearson analysis with emergent and woody wetlands. The American goldfinch and brown-headed cowbird are particularly well tied to certain human development conditions, and thus may not actually suggest the abundance of wetlands per se (Burhans and Thompson, 2006). These correlation statistics should be taken with a grain of salt as development intensity (particularly high intensity) is very strongly associated with wetlands, and additional less synanthropic birds correlate well and thus likely tolerate the presence of these urban conditions amidst the rich natural environs. Synanthropic species are known to attain extremely high numbers (Pitelka, 1942, Beissinger and Osborne, 1982, Johnston, 2001, Donnelly and Marzluff, 2006). On the other hand, the Western wood-pewee has been identified as a riparian specialist in the Pacific Northwest, and it seems likely many of the habitat generalists here, especially song sparrow, are attracted directly by the riparian conditions (Lehmkuhl et al., 2007).

Warbling vireos, common yellowthroats, and red-winged blackbirds are additional passerine species strongly associated with wetlands: the warbling vireo especially in riparian situations, and the yellowthroat and red-winged blackbird in low wetland vegetation (Lehmkuhl et al., 2007). Not one of these three species bare strong correlations with open water; thus they demonstrate the substantial differences vegetated and non-vegetated aqueous habitats have from one another in terms of importance to bird population composition.

Swainson's thrush, while ostensibly an upland bird in the Portland study, likely as a result of the lack of forest along detectable streams in the environmental matrix, are, like other known forest-breeders, found to prefer nesting in low broadleaf vegetation - a vegetation commonly associated with riparian woods (Johnson and O'Neal, 2001, Donnelly and Marzluff, 2006, Lehmkuhl et al., 2007). Other Wetland indicators are simply known habitat generalists to varying degrees, including spotted towhees, black-capped chickadees, and song sparrows (Smith et Al., 1997). Pearson's correlation in this study testifies for much of this. They are three of the most common and ubiquitous species in the study; though they obviously seem to thrive in the vicinity of water in Portland. The house wren on the other hand is a relatively scarce bird that while known to inhabit low woody vegetation, in the study is only significantly positively correlated with emergent wetland and woody wetlands (Smith et al., 1997). 
The non-native, synanthropic, and highly abundant starling is a quite mobile flocking bird. There is a chance the bird makes significant use of the ample low-structure vegetationboth wet and well drained that is present, as well as the mass of human structures. Similarly, several swallows, particularly barn and cliff swallows, and possibly including the unclassified indicator species, make use of buildings for nesting and roosting, as well as water bodies as sources of insect sustenance (Lundholm, 2011). The bald eagle (Only present in the least reduced matrix), behaves in much the same way as a predator of aquatic vertebrates and other larger prey that often nests in large forest trees and snags, including those in Forest Park (Deschler et al., 2012).

Bullock's oriole, while quite rare in the Portland study, occurred in several of the large Wetland sites in the city, likely in connection with the riparian tree canopy conditions, which were of course reduced to narrow strips. Additional wetland indicators include those well adapted to shrub and forest conditions. Brown creepers are the most forest associated of Wetland indicative birds. Interestingly the bird did not show a strong Pearson correlation with any canopy related variables. The reason for this may be tied to the importance of riparian and wetland trees and snags for this bark-probing bird (Hagar, 1999). Evidence of such bottomland woodlands is fine in scale, and is thus absent to scarce in the GIS data.

Examples of Communities Plus Importance of Landscape Heterogeneity and Wetland/Riparian Habitat

The wetland sites bore the greatest species richness at about 21.38 species ( $S D=4.51)$, followed closely by the Urban sites with 19.06 (SD=6.14). Forested sites had significantly fewer species on average than either Wetland or Built sites with 13.91 bird species $(S D=4.96)$.

Forest sites ranged from just three species identified to as much as 24 species. Not surprisingly, diversity in forested sites seemed correlated with synanthropic and habitat generalist species such as black-capped chickadees, Northern flickers, and song sparrows, as is the case with the most species rich sites of the category. Subtle variation and additional habitat on the landscape also contributes to diversity in the Forest group. This is consistent with text on the species present, as well as forests in our region (Brown, 1985, Hagar, 1999).

Based on Google Earth images, factors like presents of small stream that may provide shrubby, herbaceous, or emergent conditions favorable to the riparian birds; as well as birds of forest openings such as song sparrows and spotted towhees. Presents of the roads and small residential areas with associated clearings may also favor the edge-adapted sparrow and towhee, as well as more synanthropic species. Habitat generalists or birds indicative in the Built group may be benefitting particularly from residential development along the forest interface. Second growth deciduous tree and shrub species, plus bird feeders and additional plants favored by people are beneficial to some forest birds, as well as more generalist or tolerant taxa (Donnelly and Marzluff, 2006, Adler and Tanner, 2013).

Some species-rich forest sites are located adjacent to large fields and pastures, or manicured locations known to contain plantings of hummingbird-attractive and otherwise native forbs and shrubs. All this may contribute to the success of birds like crows, American 
goldfinches, and Anna's hummingbirds, among others. Indeed several birds determined to be negatively or un-correlated with forest and woodland conditions by Pearson' analysis are in fact forest preferring, or forest accepting under such conditions.

In contrast to the richest forest sites, the least rich site (3 species) only contained forest indicators. Possibilities for this may include more forest interior conditions and less riparian vegetation due to steeper stream banks plus a small and narrow flow in the creek present. Various water quality factors may impact aquatic invertebrate life, and thus the quality of habitat to riparian associated passerines. There appear to also be sharper elevation changes within the buffer, as well as busy roadways. These factors may be unfavorable to several species, or may make bird detection more difficult. Other non-diverse Forest sites are to be found in the same general area, with similar forest conditions.

Not surprisingly, the most species rich wetland sites also contained synanthropic species more indicative of the Built group. It has already been noted that many Wetland indicators are in fact highly synanthropic, and likely fall into the category to some extent due to the proximity Portland wetlands have to high-intensity urban development; although several Wetland indicators, and certainly additional species occurring around wetland sites bear qualities of habitat generalists. Species rich Wetland sites may support synanthropic species as crows, mallards, and starlings, as well as Forest indicators as the Swainson's thrush, and the treedwelling brown creeper-the latter two species certainly benefiting from strips of riparian woods.

Wetland sites with the most richness contain particularly ample restored gramanoid and woody wetland vegetation, where non-native species are removed and native species are planted, along with restoration of a more natural flood/flow regime in the streams and the use of plants on the perimeter of the landscape for absorption of factory or landfill runoff. While tree canopy exists, it is largely limited to thin stretches. Thus the presents of forest birds is due to tolerance to such distribution morphology; or else the use of additional wetland woody vegetation and snags. Narrow expanses of trees are known to support and connect birds with more voluminous and more preferred woodland, even those running through urban areas (Fernandez-Juricic, 2000). This seems like a suitable explanation for the thrush and Wetlandindicative brown creeper; yet the majority of birds in the site buffer zone included those of wetlands in general, or low standing woody and herbaceous vegetation. Over 30 species could be seen in several of these sites, including as many as three Forest indicators.

By contrast, the least diverse of the wetland sites (14 species) contained only contained two Built and one Forest indicator. The site differed from the species rich Wetlands in being dominated by what is interpreted by GIS data as open water, along with a largely forested and snag covered island. In fact, un-classified mud-flats or sandbars, combined with the open water, and some riparian woods do manage to support Wetland indicators, as well as an individual example of the scarce and non-indicative spotted sandpiper. The lack of emergent or flood prone vegetation seems to explain a general lack of local diversity. 
The capacity of the water to host invertebrate life indicative of quality aquatic conditions (may flies, stone flies, and caddisflies), along with vertebrate life, such as amphibians and fish that rely both on ample prey and suitable substrates are likely limiting factors to diversity and certain particular species in the Wetland group (Deschler et al., 2012). Lack of fish runs in the lower level streams may well explain absents or scarcity of numerous avian species in the study, and heavily forested locations in particular. However, as open water at a coarse scale did not prove significant in the ENVFIT analysis, small water bodies may be more attractive or of generally greater significance to birds than large bodies as the Willamette.

The greatest variation in species diversity was found among urban sites (Wetland and Built), a fact not surprising given the variation in environmental conditions and the fact the Built category bore the greatest number of sites. In addition to indicator species, the most diverse site in the entire study (34 species), contained 13 wetland indicators, and numerous Forest indicators, or woodland correlates--statistics most certainly due to small wetland and treed habitat in the landscape. The very rare Brewer's blackbird sightings came in such sites. This latter fact is very likely due to the presents of pastureland and similarly profiled, un-treed and developed landscape, rare variables that lost there value in the ENVFIT process as infrequent species were eliminated from the matrix (Martin, 2002, Dunn, 2006).

Overall it seems it is the heterogeneity, and perhaps quality of habitat conditions, rather than the human development alone that explains the bird diversity here. The small but definite presents of vegetated wetlands and/or riparian conditions with dense vegetation and snags certainly accounts for or plays a role in the presents of many of the species throughout these diverse Built landscapes. While the presents of agricultural open space can be a defining factor in some instances, other sites are primarily forested. When it comes to Built's forest land, the composition, location, and morphology of distribution over the landscape may be defining factors that explain the unique assemblage of species in primarily wooded sites here. Birds include the rare Townsend's warbler and varied thrush, as well as additional non-Forest associates. High diversity is seen in built sites with and without significant woodland. Exact species assemblages are distinct in each; but both types of Built sites are none the less in close proximity to dense residential and other forms of development, including many roads. Synanthropic birds are also present amidst the rich species counts. Built sites with little diversity may suffer from a lack in native understory vegetation, extensive native habitat in general and un-remediated influence of nearby industrial space.

Conservation Implications

Species richness generally increased towards the cities high-development inner core, with the most diverse data collection areas usually containing distinct landscape heterogeneity, and with wetlands and different degrees of human development comprising the majority of the landscape. This is by and large consistent with reports from Donnelly and Marzluff (2006).

The results of this Portland-based study show a uniquely positive paradigm with regards to trends in diversity and development in the Pacific Northwest region when it comes to the overall trend in richness from the rural/exurban metropolitan fringes to the core of urbania. 
Urban wetlands in Portland, while few and small today, continue to support great avian variety due to the importance or use of wetlands by different taxa, as well as the adjacency of additional habitat-especially built structures and narrow residual woodlands, which added additional species to the mix that would otherwise be scarce to absent.

Aqueous landscape factors vary more around developed space than their importance to richness would suggest. Naturally vegetated habitats, like shrublands, plus woody and emergent wetlands and perhaps pastures, crop lands and canopy cover survive intact to differing extents amidst development and in proximity to one another, thus playing strong mutualistic effects on diversity. Upstream forest habitat, and extensive upland buffers around wetlands such as those at the Big Four Corners restoration area data collection sites may consistently and effectively prevent stream down-cutting and transport of pollutants, while supporting soil recharge where bird communities are most diverse (Schueler, 1994, Arnold and Gibbons, 1996, Finkenbine et al., 2000, Faulkner, 2004).Differences in species compositions and subtle landscape variables make it difficult to compare and draw conclusions from other publications, including those with data collected from the moist Pacific Northwest. The complex contrasts between study results do suggest complexities in habitat demands, and perhaps differences in behavior depending on regional geography (Hagar, 1999). It may be that the lack of extensive forest and other habitats along major streams may relate to the scarcity in certain species; though many small streams of possible importance for the maintenance of healthy riparian conditions were difficult to observe both via the environmental matrix data and Google Earth imaging.

The high richness, and great number of indicator species go to show the particular importance of wetlands, even when at a small scale, and amidst pressures from the urban landscape, including pollution, Invasive species, traffic, exclusion of and human conflict with certain wildlife, etc. This is in contrast to studies in the Northwest, including Donnelly and Marzluff (2006), as well as studies elsewhere that suggest collapse of native bird richness as riparian corridors enter deep into cityscapes (See also: Smith and Schaefer, 1992, Cubbedge and Nilon, 1993, Rottenborn, 1999). While such factors as pressures from habitat loss, and abundance of alien and competitive synanthropic species may be profoundly detrimental in Portland, here wetlands support both birds dependent on aquatic and damp/literal resources, as well as species adapted to varying degrees of disturbance and subsequent vegetation structures. Most such birds in this study are known to prefer riparian conditions; although not all of this study's Wetland indicators are seen by The Oregon Department of Fish and Wildlife (ODFW) as species associated with wetland habitat: exceptions being marsh wrens, swallows, wood ducks, great blue herons, Canada geese, and red-winged blackbirds. As expected, ospreys, marsh wrens, and belted kingfishers are also described as birds found in association with wetland bodies. Several other birds in this Studies wetland group are noted as inhabitants of deciduous shrub and woodland by the ODFW: yellow warbler, warbling vireo, and willow flycatcher (ODFW, 2015).

The Oregon Office of the U.S. Fish and Wildlife service names three species found in this Portland study as "Species of Special Concern": the band-tailed pigeon, olive-sided flycatcher, and willow flycatcher. Of these, only the willow flycatcher appears as an indicator species, as it 
is an important, common, and diagnostic bird of the Wetland sites, thus suggesting the importance of such a landscape. Another major Wetland indicator, the yellow warbler, is said by Oregon Fish and Wildlife to have suffered major declines, especially in urban areas in the $20^{\text {th }}$ century. Band-tailed pigeons bare significant correlation with coniferous forest in the study, but do not show up as a Forest indicator, thus suggesting they can be found in wooded landscapes extensively outside the Forest group. The habitat associations of the olive-sided flycatcher are more nebulous, though it is known to breed in Forest Park. Washington Fish and Wildlife lists the Pileated woodpecker (a Forest indicator) as a species of Special Concern, along with the non-indicative Vaux's swift (Washington Fish and Wildlife, 2015). Pileated woodpeckers are noted to have increased in response to forest maturation in Forest Park. All this said, we can see once more that Portland's low lying landscape is of particular conservation importance, perhaps supporting birds not necessarily associated with water and wetland habitat indicators and non-indicators (marsh wren) of sites defined here as Wetland.

As expected, ospreys, marsh wrens, and belted kingfishers are also described as birds found in association with wetland bodies by ODFW. Several other birds in this Studies wetland group are noted as inhabitants of deciduous shrub and woodland by the ODFW: yellow warbler, warbling vireo, and willow flycatcher (ODFW, 2015).

The Oregon Office of the U.S. Fish and Wildlife service names three species found in this Portland study as "Species of Special Concern": the band-tailed pigeon, olive-sided flycatcher, and willow flycatcher. Of these, only the willow flycatcher appears as an indicator species, as it is an important, common, and diagnostic bird of the Wetland sites, thus suggesting the importance of such a landscape. Another major Wetland indicator, the yellow warbler, is said by Oregon Fish and Wildlife to have suffered major declines, especially in urban areas in the 20th century. Band-tailed pigeons bare significant correlation with coniferous forest in the study, but do not show up as a Forest indicator, thus suggesting they can be found extensively in wooded landscapes outside the Forest group. The habitat associations of the olive-sided flycatcher are more nebulous, though it is known to breed in Forest Park. Washington Fish and Wildlife lists the Pileated woodpecker (a Forest indicator) as a species of Special Concern, along with the non-indicative Vaux's swift (a species known to prefer large forest tree cavities for nesting, and more open areas for feeding) (Washington Fish and Wildlife, 2015). Pileated woodpeckers are noted to have increased in response to forest maturation in Forest Park. Cavity nesters are known to suffer in numbers from loss of suitable nesting substrates, and vegetation complexity (Schlesinger et al., 2008). All this said, we can see once more that Portland's low lying landscape is of particular conservation importance, supporting birds not necessarily associated with water and wetland habitat; but upland forests remain significant in the urban context (Lehmkuhl et al., 2007; Trammella et al., 2011).

Open habitat, with sparse or low vegetation is scarcer in the study, but is important to birds very uncommon to Portland, and limited to such particular conditions in the Pacific Northwest. The Brewer's blackbird is known to have fallen significantly in total population, but remains abundant among North American birds (Partners in Flight, 2012). Likewise, the Western meadowlark, which has also suffered major declines, and Savanah sparrow were not abundant enough to be included in the research. 
The sites categorized as Wetland were on average the most diverse and species rich, and held by far the greatest number of habitat group indicator species, followed by the Built group. This was true in spite of the Wetland group having fewer than half the number of sites as Built. While many of the Wetland indicators here are habitat generalists, as stated, the importance of such environs to non-generalist species is also clear, and is consistent with other studies (Seymour and Simmons, 2008). Forest on the contrary was of particular importance to few species; but regardless, this site group was significant and distinct in assemblage. Most notable among the species reliant on this group was the Pacific wren, which had a higher indicator value than any other bird in the entire study, and while abundant, occurred in less than one third of the sites. In addition, the other groups, especially Built, contained species known to prefer, and correlated in the study's Pearson analysis to forest conditions. The most species rich of the sites fell into the Built category. This may be due to the coexistence of significant forest with significantly sized wetlands, or abundance of certain forest types less common in the expansive canopy cover of the Forest group. Most of the forest correlates that were Built group indicators are connected with coniferous forest, including evening grosbeak and pine siskin; however, analysis of some of the forest among the expansive Built group, also suggest a link between deciduous forest and some particular rare birds in the study.

Generally small, but obviously important, and relatively robust riparian stands of cottonwood, oak, ash, and alder in the Wetland group are favored by a unique assemblage of birds. Many of the species associated with oak savannahs however, are effectively missing in our data, including indicative, sensitive and declining species like white-breasted nuthatch, acorn woodpecker, American kestrel, and Lewis's woodpecker; though existing examples of oaken bottomlands are successfully supporting willow flycatchers and yellow warblers (Lowther et al., 1999, Hagar and Stern, 2001, Poole and Gill, 2002).

The fact that extensive forest is so abundant at high elevations near the rural outskirts of the city can be seen as an indirect factor in the community assemblages closer to the urban core and vice versa as a result of species movement and linkages such as streams (Saab, 1999; Trammella et al., 2011, Alberts et al., 2013).

Many of the low level streams in Portland face continued environmental threats, including contaminant inputs, and extensive culverting, particularly near where these streams meet their mouths in heavily industrialized and densely built locales along the Willamette river. As a result, forested regions bear few substantial fish populations, and face threats to additional aquatic life. This in turn probably limits many riparian and aquatic birds, especially in the forest sites. Kingfishers, a common pescivorous bird along streams of different sizes, were a notably scarce bird in the study. Water pollutants can affect ecological communities well down or upstream and among birds (Alberts et al., 2013).

Species richness varied significantly within each group. Reasons for this are varied, but not always clear; but obviously the most species rich of the sites included abundant and complex vegetation structures, as well as landscape heterogeneity. As expected, urban and suburban development evidently contributed synanthropic species; and the most species rich of sites tended to contain a little or a relatively high degree of development, including buildings, 
parking lots, roads, and agriculture (cultivated and pasture land). Indirect effects of such development were uncertain as many habitat specialists consistently show up amidst such potential pressures; and predatory and nest parasitic species cohabit buffer areas with abundant and diverse potential victims. As discussed, the starling is quite reliant on human modification to the environment, especially via construction; though it may indeed be benefiting both from the wetlands and the un-forested conditions they represent. Crows on the other hand are negatively correlated with wetlands, and perhaps abundant wetland provides shelter from these aggressive and predatory birds. More research is needed to discern trends and other factors.

\section{Conclusion and Recommendations}

The clearest message to come from this analysis is species assemblage follows a trend from vastly forested uplands to limited low lying wetlands, with species coming and going along this course. This fact reflects not only the general trend in the land cover make-up of the study areas, but describes Portland in general, as well as a great number of cities in cool wet climates. There are unique qualities to the different habitats that also come and go along this highland to lowland, forest to building and wetland dominated landscape, including mid-elevation suburban, stream, and woodland vegetation. Cityscapes are most intense along river, lake, or coastal shores where transportation or agricultural resources have been or remain optimal. This course of development puts a conspicuous, direct, and indirect strain on the particularly diverse natural habitats of rich bottomland soils, whether they are emergent vegetation, shrub and forb, riparian forest, or open-water dominated.

The study confirms that such low-lying wet habitat is of crucial importance, typically supporting a greater bird diversity than any other landscape, even when found in close quarters with intense and abundant urban development. This in turn demonstrates the ecosystem service such habitat provides, protecting diverse life amidst and from potentially destructive forces in the landscape. This was true even where wetlands were small in size, as was the case with most wetlands in the study when compared to the large contiguous areas of forest analyzed; although the larger wetlands tended to support a wider variety of bird species to a greater and more consistent extent than the smaller wetlands found in the group designated as Built. This is somewhat consistent with studies of riparian bird assemblages that demonstrated species richness to be associated with wide channels and abundance of native woody vegetation; however, such studies also demonstrate negative correlation with housing and road density-something not demonstrably evident in Portland (Green and Baker, 2002, Peterson et al., 2013). In Portland richness was generally positively associated with development variables; though it should be noted that much of the residential development and high road density was found in the Built sites where wetlands/riparian habitats were indeed small, and richness varied considerably.

While species richness varied according to group, especially with regard to the relatively low diversity of the Forest group, each group contributed extensively to regional diversity-that is the overall diversity of birds across the Portland city region. Landscapes dominated by forests tended to host the least species richness; yet certain birds were extremely heavily tied to these 
expansive forest lands (Pacific wrens had the strongest indicator value in the study), thus suggesting their importance for conservation purposes. Upland Built lands with forest also proved critical to numerous species. The geographic analysis shows evergreen forests to be more closely tied with suburban landscapes; although the Willamette lowlands also hosts endangered or otherwise relatively rare woodland conditions, including oak bottomlands, and riparian vegetation of cottonwood, ash, willow, alder, and other deciduous species. Disturbance regimes that provide debris and snags, as well as savanna like conditions and prevention of conifer succession is imperative to this woodland. Glimpses at the residual bottomland conditions reveal the importance, not only of the woods themselves, but of natural disturbance and other natural conditions, such as stream flow, flooding, and beaver activity. Contiguous upland forest however makes up the bulk of protected landscape in Portland; and the specialization many of Portland's most common birds have to this habitat, as well as the need to better understand uncommon species here altogether makes conservation and management efforts imperative.

Some of the most species rich Wetland sites bear not only extensive wetlands, but a buffering habitat meant in part to help leach out pollutants from the urban matrix. These supply numerous members of the bird community here.

Literature on the subject of urban impacts on avian species assemblage appears inconsistent in methodology. Thus it will take more research to determine if and how urbanization factors have an effect on sensitive birds' presence and absence; but there is ample evidence that the large wetlands manage to support rare species, abundant and widespread wetland birds, and habitat generalist species within the same landscape/study grounds.

Many questions remain, not least of which concern the trends affecting some of the rarest of species detected in the study. Species like the gadwall, double-crested cormorant, cinnamon teal, and American bittern are clearly wetland species in nature, and showed up in such sites; but each occurred on no more than three occasions. Forest sites did host some rare species that were or were not removed prior to NMDS and Indicator species analysis. Northern Pygmy owls are known to inhabit and likely nest in Forest Park, though they were only seen once in the data collection (Deschler, 2012). The undetected hermit thrush and gray jay are also known Forest Park residents (Deschler et al., 2012). Nocturnal bird data would be useful.

What's more as some of the species effectively or entirely absent from the study were those preferring large fields and grassland. Savanah sparrow, Western Meadowlark, killdeer, horned lark (an endangered subspecies), and Brewer's blackbird are worth further investigation in greater Portland, as most are of special conservation concern.

Exact proportions and thresholds for individual landscape values and combinations thereof are difficult to observe. Such values may moreover compete in importance with variables not explored or observable in the study. Weather and local noise/human activity data is not consistent nor numerically normalized. It is not certain if sampling was done according to the abundance of habitat within Portland Metro. Perhaps a particular forest or wetland loving 
species is quite common in the city; but its habitat was not sampled enough to demonstrate this truth.

Species interactions may also play a significant role in community structures with in the Portland region (pressure or competition from predatory and aggressive synanthropic species, etc.); but this can scarcely be extracted from the analysis conducted here. Alien plants like English ivy, and there invasion/removal, and the effects on as well as reintroduction of native plant species may have broad if indirect implications for birds (Reichard et al., 2001, Hennings, 2002, Schneider and Miller, 2014). Factors such as specific plant species-make-up may be substantial in terms of nesting, roosting, and food resources for avian species within a particular land cover classification (Ikin et al., 2013). Waste and runoff from impervious or compacted surfaces not recognized in the geodata might also be playing a part. Particularly vague are the coarse scale geographic variables that are undetectable in many settings due to sparseness, even with Google Earth. Efforts to conduct point-counts at locations within suburban and non-"natural" sites with a focus on native plant presents are important (Blair, 1996).

Other geographic information analysis may be warranted, including factors such as viewshed and aspect of slopes present. While road density was considered in the environmental matrix, traffic may prove to be of value as well.

These are just a few examples of how additional information can potentially add to our understanding of the Portland environment and how to manage it. In addition, one may wish to make adjustments to the grouping of sites for indicator species designation. This may include creating different thresholds for group inclusion (sites with less forest may be considered for the Forest group for example). More groups can be created, for example one with sites containing extensive riparian woodlands or forest edge. The large Built group can easily be split in two or decreased in size with simultaneous expansion of Wetland and/or Forest. Different criteria based on the significant variables from ENVFIT can be used to form groups.

More recent inputs to the data collection, along with disregarded data would be supremely helpful. This work never the less should give a clear image as to where the most species rich types of habitat may be found in Portland, and the reasons for this diversity. It should offer some perspective as to the weight that should be given to conservation priorities. Management practices that promote heterogeneity at varying scales--especially with concern for rare habitat types such as oak savannahs--can prove highly positive for regional diversity. Ongoing restoration efforts of wetlands in Portland should proceed with understanding for the variety of vegetation and hydrologic structures that once existed while attempting to comprehend the effects of the heterogeneous surrounding landscape present today. While restoration of natural or near-natural conditions through restoration over large swaths of land are important, streams, and small stretches of riparian vegetation and other landscapes can be highly diverse and ecologically functional. Land owners and landscape designers/restorers should consider their individual rolls in maintaining diversity through supporting food sources and shelter by way of native and perhaps exotic trees, shrubs, forbs/grasses, and other resources. Large structures such as buildings, like bridges and human dwellings, and city-bound 
large trees and snags are regularly paramount for great numbers of species as food and shelter/nesting at a landscape and regional level; but both responsibility and further research is required in this domain. Meanwhile, Portland can not only assist present day breeding birds, but can also work to attract species nearly or completely extirpated.

Acknowledgements:

Matthew Dorfman should be given as much credit as possible due to his grasp of statistical analysis and GIS, plus his ability to describe graphics and processes, and his willingness to assist throughout. 
Bibliography:

Acevedo, M. A., \& Restrepo, C. (January 01, 2008). Land-cover and land-use change and its contribution to the large-scale organization of Puerto Rico's bird assemblages. Diversity and Distributions, 14, 1, 114-122.

Adler, Frederick R., and Tanner, Colby J. 2013; Urban Ecosystems: Ecological Principals for the Built Environment; Cambridge University Press.

Adkisson, C. S., 1996; Red Crossbill (Loxia curvirostra); In the Birds of North America, No. 2256; Poole, A., and Gill, F., eds; the Academy of Natural Sciences, Philadelphia, PA., and the American Ornithologists' Union (AOU), Washington D.C.

Alberti, M., and Marzluff. J. M., 2004; Ecological resilience in urban ecosystems: linking urban patterns to human and ecological functions; Urban Ecosystems, 7(241-265)

Alberts, Jeremy M., Sullivan, S. Maeika P., and Kautzab, A., 2013; Riparian Swallows as Integrators of Landscape Change in a Multiuse River: Implications for Aquatic-to-Terrestrial Transfers of Contaminants; Department of Biological Sciences, University of Cincinnati.

Atchison, Kelly A., and Rodewald, Amanda D., 2006; The Value of Urban Forests to Wintering Birds; Natural Areas Journal

BEISSINGER, S. R. AND OSBORNE D. R., 1982; Effects of urbanization on avian community organization.

Bernert, J. A., Eilers, J. M., Eilers, B., Blok,, J. E., Daggett, S. G., and Bierly, K. F., 1999; Recent wetlands trends (1981/82-1994) in the Willamette Valley, Oregon, USA; Wetlands 19(545-559).

Blair R. B., 1996; Land use and avian species diversity along an urban gradient; Ecological Applications 6:506-519.

Blewett, Christina M., Marzluff, John M., 2005 Effects of Urban Sprawl on Snags and the Abundance and Productivity of Cavity-Nesting Birds; The Condor, 107:678-693.

Boyd, R., 1986; Strategies of Indian burning in the Willamette Valley; Canadian Journal of Anthropology 5(65-86).

Bradley, C. A., Gibbs, S. E. J., and Altizer, S., 2008; Urban land use predicts West Nile Virus exposure in songbirds; Ecological Applications, 18(1083-1092). Ecological Applications 1810831092).

Brown, B. T., and Stevens, L. E., 1997; Winter Bald Eagle Distribution is Inversely Correlated with Human Activity Along the Colorado River, Arizona; Journal of Raptor Research, 31:1(7-10).

Brown, E. R., Editor, 1985; Management of Wildlife and Fish Habitat in Forests of Western Oregon and Washington, Part 2; U.S. Forest Service Publication R8,-F\&WL(1982-1985). 
Bub, B. R., Flaspohler, D. J., and Huckins, C. J., 2004; Riparian and upland breeding-bird assemblages along headwater streams in Michigan's Upper Peninsula; Journal of Wildlife Management 68(383-392).

Bunnell, F. L., 1999; What habitat is an island?; In: Rochelle, J. A., Lehmann, L. A., and Wisniewski, J., eds; Forest Fragmentation: wildlife and management implications; Brill, Boston, pp. 1-31

Burghardt, K. T., Tallamy, D. W., and Shriver, G. W., 2009; Impact of native plants on bird and butterfly biodiversity in suburban landscapes; Conservation Biology 23(219-224).

Burhans, D. E., and Thompson III, F. R., 2006; Songbird abundance and parasitism differ between urban and rural shrublands; Ecological Applications , 16(394-405).

Burhans, Dirk E., Root, Brian G., Shaffer, Terry L., Dey, Daniel C., 2010; Songbird Nest Survival is Invariant to Early-successional Restoration Treatments in a Large River Floodplain. The Wilson Journal of Ornithology 122, 307-317.

Cao, Y., Larsen, D. P., Hughes, R. M., Angermeier, P. L., \& Patton, T. M. (December 01, 2002). Sampling Effort Affects Multivariate Comparisons of Stream Assemblages. Journal of the North American Benthological Society, 21, 4, 701-714.

Case, T. J., 1996; Global patterns in the establishment and distribution of exotic birds; Biological Conservation 78(69-96.).

Chace, Jameson, and Walsh, John J, 2004; Urban Effects on Native Avifauna; Landscape and Urban Planning (74).

Chambers, Carol L., McComb, William C., and Tappeiner, John C., 1999; Breeding Bird Responses to Three Silvicultural Treatments in the Oregon Coast Range; Ecological Applications, Vol 9(1).

CHAPMAN, K. A. AND REICH P. B., 2007. Land use and babitat gradients determine bird community diversity and abundance in suburban, rural and reserve landscapes of Minnesota, USA. Biol Cons.

The City of Portland, Oregon, Last Accessed June 2015; Mason Flats Wetland Enhancement Project; URL: https://www.portlandoregon.gov/bes/article/358682

CLERGEAU, P., Savard J.-P . L ., MENNECHEZ C ., AND FALARDEAU C ., 1998. Bird abundance and diversity along an urban-rural gradient: a comparative study between two cities on different continents. Condor

Cooper, C. B., and Walters, J. R., 2002; Experimental evidence of disrupted dispersal causing decline of an Australian passerine in fragmented habitat; Conservation Biology, 16(471-478) 
Csuti, B. A., Kimerling, J., O’Neil, T. A., Shaughnessy, M. M., Gaines, E. P., and Huso, M. M., 1997 Atlas of Oregon Wildlife; Oregon State University Press.

Cubbedge, A. W., and Nilon, C. H., 1993; Adjacent Land Use Effects on the Flood Plain Forest Bird Community of Minnesota Valley National Wildlife Refuge; Natural Areas Journal (13).

Daggett, S. G., Boule, M. E., Bernert, J. A., Eilers, J. M., Blok, E., Peters, D., and Morlan, J., 1998; Wetland and land use changes in the Willamette Valley, Oregon: 1982 to 1994; Shapiro and Associates, Inc. Report to the Oregon Division of State Lands, Salem, OR

Deschler, John, Peterson, Kendra-Morgan, Roth, Emily, Fish, Nick, Abbaté, Mike, Lev, Deb, Dragoy, Astrid, Broshot, Nancy, Corkran, Char, Helzer, Dave, Labonte, Jim, Morzillo, Anita, Jewell, Judy, 2012; Forest Park Wildlife Report; Portland Parks and Recreation

Donnelly, R., 2002; Design of Habitat reserves and settlements for bird conservation in the seattle metropolitan area; Ph.D. dissertation, University of Washington, Seattle.

Donnelly, R., and Marzluff, J. M., 2004; Importance of Reserve Size and Landscape Context to Urban Bird Conservation; Conservation Biology, 18(733-745).

Donnelly, R., Marzluff, J., 2006; Relative Importance of Habitat Quantity, Structure, and Spatial Pattern to Birds in Urbanizing Environments; Urban Ecosystems, Vol. 9, Issue 2(99-117).

Drayton, B., and Primack, R. B., 1996; Plant species lost in an isolated conservation area in Metropolitan Boston from 1894 to 1993; Conservation Biology , 10(30-39).

Dunne, P., 2006; Pete Dunne's essential field guide companion; Houghton Mifflin, Bostton MA.

Evans, K. L., Newson, S. E., and Gaston, K. J., 2009; Habitat Influences on Urban Avian Assemblages; Ibis (101).

Faeth, S. H., Bang, C., and Saari, S., 2011; Urban biodiversity: patterns and mechanisms; Annals of the New York Academy of Sciences, 1223(69-81).

Faith, D. P., Minchin, P. R., \& Belbin, L. (April 30, 1987). Compositional Dissimilarity as a Robust Measure of Ecological Distance. Vegetatio, 69, 57-68.

Fahrig, Lenore, 1997; Relative effects of habitat loss and fragmentation on population extinction; J Wildlife Management, 61(603-610).

Fahrig, Lenore, 2003; Effects of Habitat Fragmentation on Biodiversity; Annual Reviews Ecol. Evol. Syst, 34(487-515)

Faulkner, Stephen, 2004; Urbanization Impacts on the Structure and Function of Forested Wetlands; Kluwer Academic Publishers 
Fernandez-Juricic, 2000; Avifaunal Use of Wooded Streets in an Urban Landscape; Conservation Biology, 14(513-521).

Fernández-Juricic, E., \& Jokimäki, J. (January 01, 2001). A habitat island approach to conserving birds in urban landscapes: case studies from southern and northern Europe. Biodiversity and Conservation, 10, 12, 2023-2043.

Finch, D. M., 1989; Habitat use and habitat overlap of riparian birds in three elevational zones; Ecology, 70(866-880).

Finkenbine, J.K., Atwater, J.W. and Mavinic, D.S. 2000; Stream health after urbanization. J. Am. Water Resour. Assoc.

Fisher, Joern and Lindenmayer, David B., 2007; Landscape Modification and Habitat Fragmentation: aa Synthesis; Global Ecology and Biogeography, 16(265-280).

Francis, C. D., Ortega, C. P., and Cruz, A. 2009; Noise pollution changes avian communities and species interactions; Current Biology , 19(1415-1419).

Gaston, Kevin J., 2010; Urban Ecology; Cambridge University Press.

Gates, Sara, 2013; Domestic Cats Kill Billions of Mice and Birds Per Year, Study Estimates; The Huffington Post, URL: http://www.huffingtonpost.com/2013/01/30/domestic-cats-kill-billionsmice-birds-annually-study_n_2575833.html

Gavareski, C. A. (October 01, 1976). Relation of Park Size and Vegetation to Urban Bird Populations in Seattle, Washington. The Condor, 78, 3, 375-382.

George, T. Luke, Dobkin, David S., ED., 2002; Effects of habitat fragmentation on birds in western landscapes: contrasts with paradigms from the Eastern United States. Studies in Avian Biology, 25(8-19).

Green, Douglas M., and Baker, Micheal G., 2002, Urbanization Impacts on Habitat and Bird Communities in a Sonoran Desert Ecosystem; Landscape and Urban Planning, 968(1-15).

Hagar, Joan C., 1999; Influence of riparian buffer width on bird assemblages in Western Oregon; The Journal of Wildlife Management, Vol. 63, No. 2

Hagar, Joan C., Stern, Mark A., 2001; Avifauna in Oak Woodlands of the Willamette Valley, Oregon; Northwestern Naturalist Vol 82(1)

Hansen, Andrew J., Knight, Richard L., Marzluff, John M., Powell, Scott, Brown, Kathryn, Gude, Patricia H., and Jones, Kingsford, 2005; Effects of Exurban Development on Biodiversity: Patterns, Mechanisms, and Research Needs; Ecological Applications, Vol 15(6).

Harrison, S., and Bruna, E., 1999; Habitat fragmentation and large-scale conservation: what do we know for sure?; Ecography, 22(225-232). 
Hendrickson, Nancy, Last Accessed June 2015; Big Four Courners Land Acquizition; PDF, https://www.portlandoregon.gov/bes/article/129798

Hennings, Lori A., and Edge, W. Daniel, 2002; Riparian Bird Community Structure in Portland, Oregon: Habitat, Urbanization, and Spatial Scale Patterns; The Condor, 105(188-210).

Hessburg, Paul F., and Agee, James K., 2003; An Environmental Narrative of Inland Northwest United States Forest, 1800-2000; Forest Ecology and Management, 178(23-59).

Hruska, Krunica, Dell'uomo, Antonio, Staffolani, Lara, and Torrisi Mariacristina, 2008; Influence of Urbanization on Riparian and Algal Species Composition in Two Rivers of Central Italy; EcoScience (15)

Hulse, D., Gregory, S., and Baker, J., editors., 2002; Willamette River Basin Planning Atlas: Trajectories of Environmental and Ecological Change; Oregon State University Press. Huste, A., Selmi, S., \& Boulinier, T. (June 01, 2006). Bird communities in suburban patches near Paris: Determinants of local richness in a highly fragmented landscape. Ecoscience, 13, 2, 249257.

Ikin, Karen, Knight, Emma, Lindenmayer, David B., Fisher, Joern, and Manning, Adrian D., 2013; The influence of native versus exotic streetscape vegetation on the spatial distribution of birds in suburbs and reserves; The Fenner School of Environment and Society, The Australian National University.

Johnson, D. and O'Neal, T., editors, 2001; Wildlife-habitat relationships in Oregon and Washington; Oregon State University Press.

Jokimäki, J., 2003; Spatial similarity of urban bird communities: a multiscale approach; Journal of Biogeography.

Jokimäki, J., \& Huhta, E. (January 01, 2000). Artificial Nest Predation And Abundance Of Birds Along An Urban Gradient. The Condor, 102, 4.

Jokimäki, J., \& Kaisanlahti-Jokimäki, M.-L. (August 01, 2003). Spatial similarity of urban bird communities: a multiscale approach. Journal of Biogeography, 30, 8, 1183-1193.

Kark, S., Iwaniuk, A., Schalimtzek, A., and Banker, E., 2007; Living in the city: can anyone become an "urban exploiter"?; Journal of Biogeography, 34(638-651).

Kaufman, K., 1996; Lives of North American birds; Houghton Mifflin. Boston, Massachusetts, USA.

Knapp, S., Kuhn, I., Wittig, R., et al., 2008; Urbanization causes shifts in species' trait state frequencies; Preslia , 80(375-388).

Knopf, F. L., 1985; Significance of Riparian Vegetation to Breeding Birds Across an Altitudinal Cline; From the U.S. Department of the Interior Forest Service General Technical Report, pp 105-111. 
Knopf, F. L., and Sampson, F. B., 1994; Scale Perspective of Avian Diversity in Western Riparian Ecosystems; Conservation Biology, 8(669-676).

La Sorte, F. A., and Thompson III, F. R., 2008; Poleward shifts in winter ranges of North American birds; Ecology , 88(543).

Lehmkuhl, John F., Burger Dorsey, E., Drew, Emily K., Lindsey, John P., Haggard, MaryEllen, Woodruff, Kent C., 2007; Breeding Birds in Riparian and Upland Dry Forests of the Cascade Range; Journal of Wildlife Management 71(8).

Lichstein, J. W,., Simons, T. R., and Franzreb, K. E., 2002; Landscape effects on breeding songbird abundance in managed forests; Ecological Applications, 12(836-857).

Lowther, P. E., Celada, C., Klein, N. K., Rimner, C. C., and D. A. Spector, D. A., 1999; Dendroica petechia); In The Birds of North America, No. 454; (Poole, A., and F. Gill, F., eds.); The Birds of North America, Inc.; Philadelphia, PA.

Luck, G. W., and Smallbone, L. T., 2010; Species diversity and urbanisation: patterns, drivers and implications; In K. J. Gaston, ed; Urban Ecology ; Cambridge: Cambridge University Press.

Lundholm, J. T., 2011; Urban cliffs; In I. Douglas, D. Goode, M. C. Houck, and R. Wang, eds; The Routledge Handbook of Urban Ecology . (London: Routledge,( 252-263).

Major, R. E., Gowing, G., and Kendal, C., 1996; Nest Predation in Australian Urban Environments and the Role of the Pied Currawong, Strepera graculinaation, in Australia; Australian Journal of Ecology, 21(399-409).

MARSHALL, D. B., CHILCOTE, M, WEEKS, H., 1992; Sensitive vertebrates of Oregon. Portland, OR; Oregon Department of Fish and Wildlife, Irregular Pagination.

Martin, Stephen G., 2002; Brewer's Blackbird (Euphagus cyanocephalus); in the Birds of North America, No. 616; Poole, A., and Gill, F., eds; the Birds of North America Online; Ithaca New York.

Marzluff, J. M., 2005; Island Biogeography for an Urbanizing World: How Extinction and Colonization May Determine Biological Diversity in Human-Dominated Landscapes; Urban Ecosystems, 8(157-177).

Marzluff, J. M., 2008; Island biogeography for an urbanizing world: how extinction and colonization may determine biological diversity in human-dominated landscapes; Urban Ecology, 8(355-371). Urban Ecology 8(355-371).

Marzluff, J. M., Bowman, R., and Donnelly, 2001; Avian Ecology and Conservation in an Urbanizing World; Springer.

McKinney, Richard A, March 30, 2011; Wetlands as habitat in urbanizing landscapes: Patterns of bird abundance and occupancy; Landscape and Urban Planning. 
Mills, G. S., Dunning Jr., J. B., and Bates, J. M., 1991; The relationship between breeding bird density and vegetation volume; Wilson Bulletin 103:468-479.

Naiman, R. J., Decamps, H., and Pollock, M, 1993; The Role of Riparian Corridors in Maintaining Regional Biodiversity; Ecological Applications (3).

Nassauer, Joan Iverson, 1995; Culture and Changing Landscape Structure; Landscape Ecology, Vol. 10 No. 4(229-237).

Nolan, Paul M., Stoehr, Andrew M., Hill, Geoffrey E., and McGraw, Kevin J., 2001; The Number of Provisioning Visits by House Finches Predicts the Mass of Food Delivered; The Condor.

Odell, E. A., and Knight, R. L., 2001; Songbirds and Medium-Sized Mammal Communities Associated with Exurban Development in Pitkin County, Colorado; Conservation Biology, 15(1143-1150).

Oliver, C. D., and Larson, B. C., 1996; Forest stand dynamics; John Wiley and Sons, New York.

Ohmart R. D., 1994; The effects of human-induced changes on the avifauna of western riparian habitats; Studies in Avian Biology 15:273-285.

Ordeñana, Miguel A., Crooks, Kevin R., Boydston, Erin E., Fisher, Robert N., Lyren, Lisa M., Siudyla, Shalene, Haas, Christopher D., Harris, Sierra, Hathaway, Stacie A., Turschak, Gretta M., Miles, A Keith, and Van Vuren, Dirk H; 2010; Effects of Urbanization on Carnivor Species Distribution and Richness; Journal of Mammalogy, Vol. 91, Issue 6 (1322-1331).

Oregon Fish and Wildlife Office Endangered Species Division (USFWS), Last accessed on Sept 13, 2015; Species Data - Oregon Fish and Wildlife Office; U.S. Fish and Wildlife Service, URL: http://www.fws.gov/oregonfwo/Species/Data/Default.asp\#Birds, Last updated on Nov. 25, 2014.

Oregon Wild, Last Accessed on Sept 13, 2015; Osprey - Oregon Wild; URL:

Partners in Flight, 2012; Species Assessment Database; URL: http://rmbo.org/pifdb/.

Patricelli, G. L., and Blickley, J. L., 2006; Avian communication in urban noise: causes and consequences of vocal adjustment; The Auk , 123(639-649).

Pavlik, J. and Pavlik, S., 2000; Some relationships between human impact, vegetation, and birds in urban environment; Ekologia-Bratislava 19(392-408).

Pearson, Scott F., and Manuwal, David A., 2001; Breeding bird response to riparian buffer width in managed Pacific northwest Douglas-fir forests; Ecological Applications 11:840-853.

Petersen, Kenneth L., Westmark, Amy S, 2013; Bird Use of Wetlands in a Midwestern Metropolitan Area in Relation to Adjacent Land Cover; American Midland Naturalist. 
Pickett, Steward T. A., Cadenasso, Mary L., Grove, J. Morgan, Groffman, Peter M., Band, Lawrence E., Boone, Christopher G., Burch JR., William R., Grimmond, C. Susan B., Hom, John, Jenkins, Jennifer C., Law, Neely L., Nilon, Charles H., Pouyat, Richard V., Szlavecz, Katalin, Warren, Paige S., Wilson, Matthew A., 2012; Beyond Urban Legends: An Emerging Framework of Urban Ecology As Illustrated by the Baltimore Ecosystem Study; Dirived from Bio1 Online, 2012.

Poole, A., and Gill, F., eds, 2002; The Birds of North America Online; Ithica, New York.

Poos, Mark S., Jackson, Donald A., 2011; Addressing the removal of rare species in multivariate bioassessments: The impact of methodological choices; Ecological Indicators, 18(82-90).

Porter, E. E., Forschner, B. R., and Blair, R. B., 2001; Woody Fragmentation and Canopy Fragmentation Along a Forest-to-Urban Gradient; Urban Ecosyst3ems, 5(131-151).

Reichard, S. H., Chalker-Scott, L., and Buchanan, S., 2001; Interactions Among Non-Native Plants and Birds; in Avian Ecology and Conservation in an Urbanizing World; Marzluff, J. M., Bowman, R., and Donnelly;, Kluwer Academics, Boston, MA.

Reisen, W. K., Takahashi, R. M., Carroll, B. D., and Quiring, R., 2008; Delinquent mortgages, neglected swimming pools, and West Nile virus, California; Emerging Infectious Diseases, 14(1747-1749).

Rodewald, D. A., Kerns, L., and Shustack D., 2010; Anthropogenic resource subsidies decouple predator-prey relationships; Ecological Applications , 21(936-943).

Rosenzweig, M. L., 1995; Species Diversity in Space and Time; Cambridge University Press.

Rothstein, Stephen I., Verner, J., and Stevens, E., 1984; Radio Tracking Confirms a Unique Diurnal Pattern of Spatial Occurrence in the Parasitic Brown-Headed Cowbird; Ecology, 65(7788).

Rottenborn, Stephen C.; 1999, Predicting the Impacts of Urbanization on Riparian Bird Communities; Stanford University.

Rutz, C. (September 01, 2008). The establishment of an urban bird population. Journal of Animal Ecology, 77, 5, 1008-1019.

Ryder, T. B., Reitsma, R., Evens, B., and Marra, B. B., 2010; . P. Marra. Quantifying avian nest survival along an urbanization gradient using citizen-and scientist generated data; Ecological Applications , 20 (419-426).

Saab, Victoria, 1999; Importance of Spatial Scale to Habitat Use by Breeding Birds in Riparian Forest: A Hierarchical Analysis; Ecological Applications, Vol. 9, Issue 1

Sabo, J. L., Sponseller, R., Dixon, M., Gade, K., Harms, T., Heffernan, J., Jani, A., Katz, G., Soykan, C., Watts, J., and Welter, A., 2005; Riparian zones increase regional species richness by harboring different, not more, species; Ecology 86(56-62). 
Schaefer V., 1994; Urban biodiversity. Pages 307-318 in L. E. Harding and E. McCullum, editors; Biodiversity in British Columbia; Environment Canada, Canadian

Wildlife Service, Vancouver, British Columbia, Canada.

Schlesinger, M. D., Manley, P. N., and Holyoak, M, 2008; Distinguishing Stressors Acting on Land Bird Communities in an Urbanizing Environment; Ecology (89).

Schneider, Sarah C., Miller, James R., 2014; Response of Avian Communities to Invasive Vegetation in Urban Forest Fragments; the Condor, 116(59-471).

Schueler, T., 1994; The importance of imperviousness. Watershed Prot. Tech.

Schumaker, Nathan H., Ernst, Ted, White, Denis, Baker, Joan, and Haggerty, Patti, 2003; Projecting Wildlife Responses to Alternative Future Landscapes in Oregon's Willamette Basin; Environmental Protection Agency.

Seymour, C. L., and Simmons, R. E.; Can Severely Fragmented Patches of Riparian Vegetation Still be Important for Arid-Land Bird Diversity?; Journal of Arid Environments (72).

Shochat, E. (September 01, 2004). Credit or debit? Resource input changes population dynamics of city-slicker birds. Oikos, 106, 3, 622-626.

Shochat, E., Warren, P. S., Faeth, S. H., Mclntyre, N. E., and Hope, D., 2006; From patterns to emerging processes in mechanistic urban ecology; Trends in Ecology \& Evolution , 21(186-191).

Shochat, E., Lerman, S. B., Katti, M., and Lewis, D. B., 2004; Linking optimal foraging behavior to bird community structure in an urban-desert landscape: field experiments with artificial food patches; The American Naturalist, 164(232-243).

Small, C., and Kohen, J. E., 2004; Continental physiography, climate and the global distribution of human population; Current Anthropology, 45(269-277).

Smith, R. J., and Schaefer, J. M., 1992; Avian Characteristics of an Urban Riparian Strip Corridor; Wilson Bulletin (104).

Smith, M. R., Mattocks Jr., P. W., and Cassidy, K. M., 1997; Breeding birds of Washington State. Volume 4; in Cassidy, K. M., Grue, C. E., Smith, M. R., and Dvornich, K. M., editors, Washington State Gap Analysis Final Report; Seattle Audubon Society Publications in Zoology. No. 1, Seattle, Washington, USA.

Speight, M. R., Hails, R. S., Gilbert, M., and Foggo, A., 1998; Horse chestnut scale ( Pulvinaria regalis) (Homoptera:Coccidae) and urban host tree environment; Ecology , 79(1503-1513).

Stalmaster, M. V., and J.L. Kaiser, 1998; Effects of Recreational Activity on Wintering Bald Eagles; Wildlife Monographs, 137(1-46). 
Taft, Oriane W., and Haig Susan M, 2003; Historical Wetlands in Oregon's Willamette Valley: Implications for Restoration of Winter Waterbird Habitat; Wetlands 23(1)

Tallamy, D. W., 2007; Bringing Nature Home: How Native Plants Sustain Wildlife in Our Gardens (London: Timber Press.

Tewksbury, J. J., Hejl, S. L., and Martin, T. E., 1998; Breeding productivity does not decline with increasing fragmentation in a western landscape; Ecology, 79(2890-2903).

Titus, J. H.,., Christy, J. A., VanderSchaaf, D., Kagan, J. S., and Alverson, E. R., 1996; Native wetland, riparian, and upland plant communities and their biota in the Willamette Valley, Oregon; Final Project Report to U.S. Environmental Protection Agency. Oregon Natural Heritage Program, The Nature Conservancy, Portland, Oregon, USA.

Thomas, J. A., Bourn, N. A. D., Clarke, R. T., Stewart, K. E., Simcox, D. J., Pearman, G. S., Curtis, R., and Goodger, B., 2001; The quality and isolation of habitat patches both determine where butterflies persist in fragmented landscapes; Proceedings of the Royal Society of London, B268(1791-1796).

Thompson, Frank R., 1994; Temporal and Spatial Patterns of Breeding Brown-headed Cowbirds in the Midwestern United States; Awk 111(979-990).

Thompson, Frank R., and Dijak, W. D., 2000; Differences in Movements, Home Range, and Habitat Preferences of Female Brown-Headed Cowbirds in Three Midwestern Landscapes; in Smith, J. N., Cook, T. L., Rothstein, S. I., Robinson, S.K., and Sealy, S. eds; Ecology and Management of Cowbirds and Their Associate Hosts; University of Texis Press, Austin, TX. G.,

Thompson, Frank R., Donovan, Therese M., DeGraph, Richard M., et al., 2002; A Multi-Scale Perspective of the Effects of Forest-Fragmentation on Birds in Eastern Forests; Studies in Avian Biology No. 25

Trammella, Jamie, Weisberg, Peter J., Bassett, Scott, 2011; Avian Response to Urbanization in the Arid Riparian Context of Reno; University of Nevada, Reno

Washington Department of Fish and Wildlife (WDFW), Last visited on Sept 12, 2015; Washington State Species of Concern Lists;URL: http://www.oregonwild.org/wildlife/osprey, Last Updated in 2014.

Wilcove, D. S., 1985; Nest Predation in Forest Tracts and the Decline of Migratory Songbirds; Ecol., 66(1211-1254).

Wright, A. L., Hayward, G. D., Matsuoka, S. M., and Hayward, P. H., 1998; Townsend's Warbler (Dendroica townsendi); In The Birds of North America, No. 333 (Poole, A., and F. Gill, F., eds.); The Birds of North America, Inc.; Philadelphia, PA. 